Albada, A., Ausems, M.G.E.M., Bensing, J.M., Dulmen, S. van. Tailored information about cancer risk and screening: a systematic review. Patient Education and Counseling: 2009, 77 (2), 155-171)

\begin{tabular}{|l|l|}
\hline $\begin{array}{l}\text { Postprint } \\
\text { Version }\end{array}$ & 1.0 \\
\hline $\begin{array}{l}\text { Journal website } \\
\text { Pubmed link }\end{array}$ & $\underline{\text { http://dx.doi.org/10.1016/j.pec.2009.03.005 }}$ \\
\hline DOI & $\underline{1 t p: / / \text { www.ncbi.nlm.nih.gov/pubmed/19376676 }}$ \\
\hline
\end{tabular}

This is a NIVEL certified Post Print, more info at http://www.nivel.eu

\title{
Tailored information about cancer risk and screening: A systematic review
}

\author{
AKKe AlBADA ${ }^{\mathrm{a}}$, MARGREet G.E.M. AUSEMS ${ }^{\mathrm{b}}$, JOZIEN M. BENSING ${ }^{\mathrm{a}, \mathrm{c}}$, AND SANDRA VAN \\ DULMEN $^{\mathrm{a}}$ \\ ${ }^{a}$ NIVEL (Netherlands Institute for Health Services Research), Utrecht, The Netherlands \\ ${ }^{b}$ Department of Medical Genetics, University Medical Centre Utrecht, Utrecht, The \\ Netherlands \\ ${ }^{c}$ Department of Health Psychology, Utrecht University, Utrecht, The Netherlands
}

\begin{abstract}
Objective

To study interventions that provide people with information about cancer risk and about screening that is tailored to their personal characteristics. We assess the tailoring characteristics, theory base and effects on risk perception, knowledge and screening behavior of these interventions.

\section{Methods}

A systematic literature review in this field was performed. PubMed, EMBASE, PsychINFO, CINAHL and Cochrane databases were searched. Forty studies fulfilled all inclusion criteria. Methodological quality was assessed and a best evidence synthesis conducted for the 28 randomized controlled trials without co-intervention or with similar cointervention in intervention and control group.
\end{abstract}

\section{Results}

Most included studies evaluated an intervention aiming to promote cancer screening. The majority of articles (30) evaluated information that was tailored based on variables related to behavior change, sometimes combined with cancer risk factors. Ten other articles described an intervention that tailored information based on risk factors only.

\section{Conclusion}

Information that was tailored based on behavior change variables increased realistic perception of cancer risks and knowledge of cancer compared to generic information. Also, information tailored to individuals' risk factors increased realistic risk perception compared to generic information.

\section{Practice implications}

To improve cancer risk perception and knowledge health providers could better give patients information about cancer risk and screening that is tailored to their personal characteristics than generic information.

\section{INTRODUCTION}

In cancer risk communication the presentation of information is critical for understanding and accepting risk estimations and subsequent decision-making. Optimal communication of 
cancer risk information must effectively translate the risk and its associated factors to a conceptual level understandable to the recipient [1]. Subsequent behavioral change might depend on the perceived severity of the health consequences and the efficacy and costs of preventive behavior [2]. A sense of personal susceptibility could be achieved by providing information tailored to individual risk factors. Tailoring risk communication to individual pre-existing risk perceptions [3] and risk beliefs [4] might increase effectiveness of information about cancer risks and screening options [5].

The number of interventions providing patients with information tailored to individual characteristics, either printed or web-based [6], is growing rapidly. According to Kreuter et al. [7] tailored information is intended to reach one specific person and is therefore based on individual characteristics related to the outcome of interest, derived from an individual assessment. Both information content and presentation can be tailored [8]. Individually tailored information is often confused with targeted or personalized messages. According to Kreuter et al. [7], an intervention is targeted when it is intended to reach some specific subgroup of the general population, usually based on one or more demographic characteristics shared by its members. Information is considered personalized when it is adjusted only to population-based demographic data, e.g., the respondent's name. Tailored information is adapted to individual characteristics and is therefore theorized to stimulate cognitive activity. According to the Elaboration Likelihood Model [9] greater cognitive activity enhances thoughtful consideration and evaluation, and thus centrally processing information. Centrally established attitudes are thought to be more enduring, more stable against contra argumentation and better predictors of health behavior. Indeed, a study using EEG measurements revealed that people reading tailored, as opposed to generic, i.e., standard, information had stronger attention processes [10].

So far, most computer-tailored interventions aim at health behavior change in disease prevention [11], such as smoking cessation [12] and [13], diet [14] and [15] and physical exercise [15]. A recent meta-analysis by Noar et al. [11] showed increased effects of tailored print interventions on behavior change compared to generic information. Another review found increased behavior change of tailored compared to targeted or personalized information [16]. Reviews of tailored interventions for smoking cessation and dietary behavior show that computer-tailored information is more likely to be read, remembered and experienced as personally relevant compared to standard materials [13], [14] and [15]. In 1999 Rimer and Glassman [1] conducted a review of tailored print materials in cancer risk communication, identifying tailored prints concerning mammography use, hormone replacement therapy, health risk appraisal and genetic susceptibility to cancer. Rimer et al. concluded that tailored information may be an effective medium for cancer risk communication, but more evidence is needed. More recently, Noar et al. found that tailored print behavior change interventions were effective for increasing screening uptake, including mammography and pap-test [11]. Effective interventions were found to be tailored based on demographics, behavior and theoretical concepts from health behavior change theories. To assess the effects of tailoring specifically for information about cancer risks and screening we conducted a review including print as well as computer-delivered information and focusing not only on screening behavior as an outcome measure, but also on risk perception and cancer knowledge.

The following research questions have been formulated:

1. Which tailoring characteristics are used in interventions providing tailored information about cancer risk and/or screening?

2. On which theories are the tailoring characteristics based?

3. What effects are found of tailored interventions on risk perception, cancer knowledge and screening behavior? 
Albada, A., Ausems, M.G.E.M., Bensing, J.M., Dulmen, S. van. Tailored information about cancer risk and screening: a systematic review. Patient Education and Counseling: 2009

\section{METHODS}

The systematic review was conducted in accordance with a predefined research protocol, describing the following systematic processes: search strategy, selection, data extraction and quality assessment [17].

\subsection{Search strategy for identification of studies}

We defined the following inclusion criteria:

1. The article describes an intervention through which information is given to patients or individuals at risk of developing cancer

2. The main objective of the information is to inform people about cancer risks, screening options, cancer genetic counseling and DNA testing

3. The information is delivered by computer (e.g., cd-rom or internet) or as printed material (e.g., letter or leaflet) in at least one of the research groups

4. The information is tailored based on more than one variable using algorithms

5. The outcome variables include cancer risk perception or knowledge or behavior related to cancer screening

We searched the international bibliographical databases PubMed, EMBASE, CINAHL, PsychINFO, and Cochrane library in June 2007 with a sensitive search strategy without limitations by country, language, year or type of publication. Numerous keywords were used in combination in the search, including internet, print, information, cancer and tailor(ed). This strategy was formulated in PubMed and adapted to the other databases.

Search strategy in PubMed: (computer OR internet OR web OR CDrom OR print* OR letter* OR leaflet* OR brochure* OR pamphlet* OR booklet* OR material* OR message* OR postcard* OR patient information OR patient education OR counselee information OR counselee education) AND (genetic counseling OR genetic screening OR genetic testing OR hereditary OR cancer) AND (tailor* OR individuali?ed OR match* OR personali*)

\subsection{Selection}

A total of 7878 non-duplicate references were found (see Fig. 1) and imported in Reference Manager ${ }^{\odot}$. Only full text articles published in peer-reviewed journals were included. All references identified in the literature search were studied by title and (if available) abstract on agreement with all of the inclusion criteria.

\section{[FIGURE 1]}

The first reviewer examined all references and the second reviewer studied a $10 \%$ random sample. Agreement between reviewers was high (98\% and Cohen's kappa .60). In total 148 references were included in this first selection round. In the second selection round, all articles were studied full text by two reviewers independently. Differences were discussed until agreement. Thirty-seven of the 148 studies met all five inclusion criteria.

Additionally, reference lists of the included studies were screened by title by the first reviewer. References that could possibly meet all inclusion criteria were screened by abstract. Nine articles were included in this round and were hence screened full text by two reviewers independently. Three articles from the reference lists were finally included in the review [18], [19] and [20]. Added to the 37 articles found earlier, this resulted in a total of 40 included articles.

\subsection{Data extraction}

Data were extracted from each article by two reviewers independently using a predefined data extraction form (see Appendix A). Intervention and population characteristics, recruitment, outcome and limitations were documented. These data were summarized in data extraction Table 1 and Table 2. The study, population and intervention characteristics of all 40 studies are described in the results. 
Albada, A., Ausems, M.G.E.M., Bensing, J.M., Dulmen, S. van. Tailored information about cancer risk and screening: a systematic review. Patient Education and Counseling: 2009

\section{[TABLE 1]}

\section{[TABLE 2]}

\subsection{Quality assessment}

Methodological quality was described for the 28 studies with a control group receiving no intervention, standard information or usual care and without co-intervention or with similar co-intervention in intervention and control group. Quality was assessed by two reviewers independently using all seven items of the minimal checklist for assessing quality of Randomized Controlled Trials (RCTs) of the Cochrane Collaboration: (1) randomization of control/intervention, (2) allocation concealment, (3-5) blinding of participants, care providers and outcome assessors, (6) intention-to-treat analysis, (7) report of drop-out/loss to follow-up. These items are also included in the quality criteria for RCTs of the Cochrane Consumers and Communication review group [21]. Items could be scored as 'done', 'unclear' or 'not done'. Although it is encouraged to describe the study quality narratively [21], we felt that with the large number of included studies in this review use of a quality grade was inevitable. Studies were considered 'high quality' if at least $50 \%$ of the criteria (4 of 7) were scored as 'done'. This cut-off point is adjusted from Van Tulder et al. [22] and recently used in another cancer review [23]. Studies which fulfilled three of the seven quality criteria were considered 'moderate quality'. Studies with two or less criteria fulfilled were considered 'low quality'. Differences in quality assessment between reviewers were resolved by consensus.

\subsection{Effect analysis}

Because of heterogeneity, effect analysis by a formal meta-analysis of this body of research proved difficult. As opposed to Noar et al. [11] we included the outcome variables risk perception and cancer knowledge, which were assessed with different scales. Additionally, we studied interventions with various types of delivery, e.g., letter or cd-rom. Therefore, a 'best evidence synthesis' was conducted, which, according to preset criteria, qualifies results from a sample of studies as evidence, moderate evidence, limited evidence, indicative findings or no/insufficient evidence [24]. To ensure that intervention effects can be attributed to a tailored intervention, only studies which avoided co-interventions or had similar cointerventions in control and intervention group were included in the best evidence synthesis. The synthesis takes into account the design, the methodological quality and the outcomes of the studies (see Appendix B).

\section{RESULTS}

\subsection{Description of included studies}

\subsubsection{Study characteristics}

Publication years varied from 1992 [25] to 2007 [26] and [27], with most articles being published after 2000. Because tailoring of information with use of algorithms is preferably conducted by a computer, the technique was infrequently used before the 1990s and is becoming more mainstream. Most publications before 2000 described tailored print materials, whereas computer-delivered interventions were only described in publications from 2000 onwards.

All but one of the studies $(n=39)$ were carried out with populations from the USA [28]. All papers were in English. Several articles reported on the same study, often presenting results of different follow-up measurements, e.g., two articles by Kreuter and Strecher [19] and [20], two by Rimer et al. [29] and [30] and two by Valanis et al. [31] and [32]. 


\subsubsection{Population characteristics}

Most articles $(\mathrm{n}=35)$ described a study with participants at population risk level for cancer. A majority of these studies $(n=30)$ evaluated an intervention aimed at primary care patients, either contacted in a waiting room or by invitation letter [18], [19], [20], [26], [27], [28], [29], [30], [31], [32], [33], [34], [35], [36], [37], [38], [39], [40], [41], [42], [43], [44], [45], [46], [47], [48], [49], [50], [51] and [52]. Two studies had self-selected participants that responded to a newspaper advertisement [53] or called a cancer information centre [54]. Furthermore, two interventions were workplace-based [55] and [56] and one was churchbased [57]. Five interventions aimed at high-risk respondents, viz. persons with abnormal screening outcome [25] or a cancer history [58], first degree family members of cancer patients [59] and [60] and counselees in cancer genetic counseling [61]. Twenty-four studies only included female respondents, these were mostly evaluations of interventions aiming to increase mammography use.

\subsubsection{Intervention characteristics}

A large majority of the interventions $(n=37)$ comprised tailored materials, such as letters, booklets or magazines. Six interventions were computer-delivered [33], [36], [37], [39], [45] and [51]. These programs were used by participants at care facilities, often shortly before a scheduled consultation. All but one intervention used single contacts, this one study investigated the effect of a booster dose of tailored information [26]. All but two interventions tailored information with use of a computer [25] and [35].

A large number of articles $(n=19)$ investigated an intervention providing information about breast cancer risk and screening [18], [26], [27], [29], [30], [33], [34], [35], [39], [40], [41], [43], [46], [47], [49], [50], [52], [59] and [61]. Six studies investigated an intervention concerning both breast and ovarian or cervical cancer [31], [32], [38], [48], [55] and [61]. One intervention aimed at an increase of pap-test rate and focused on cervical cancer only [25]. Also seven interventions provided information about colorectal or colon cancer risks [36], [37], [51], [53], [54], [56] and [57]. Two articles studied an intervention concerning general or several cancer risks [19] and [20], two interventions focused on skin cancer [28] and [60], two on lung cancer [42] and [58] and one on prostate cancer [44].

\subsection{Tailoring variables}

Most interventions ( $\mathrm{n}=30$ ) were tailored based on variables related to behavior change, including barriers to change, stages of change, beliefs about cancer screening and previous health behavior, e.g., screening history. These so called behavioral constructs were used to adapt a message to individual characteristics and/or to provide feedback on the psychological or behavioral state. One of these interventions additionally adapted information to cultural constructs, specifically racial pride, spirituality and collectivism [40]. Seven interventions also provided cancer risk factor feedback. Ten interventions tailored information only on cancer risk factors, providing personal cancer risk estimation as feedback. It was often unclear how information was adapted to a tailoring variable, although some articles present a table with components of the tailored and non-tailored messages [30], [35] and [38].

\subsection{Theoretical foundations of the tailoring}

All but three [19], [43] and [47] articles about interventions that build on behavioral constructs, specified the theoretical base of the tailoring variables. Many of these interventions were based on more than one theory. Prochaska's Transtheoretical Model (TTM) or Stages of Change Model was referred to as the theoretical idea behind the tailoring variables in 20 articles [18], [20], [26], [27], [29], [30], [31], [33], [34], [37], [39], [41], [45], [46], [48], [50], [54], [55], [57] and [60]. This model distinguishes five stages of change through which individuals move when changing their behavior, from precontemplation to maintenance of the new behavior. Based on this theory, information was adapted to readers' stage of change, e.g., in relation to mammography screening [26], [27] and [50]. Eleven 
articles [20], [26], [27], [28], [33], [34], [38], [49], [54], [57] and [60] described an intervention with a tailoring strategy based on the Health Belief Model (HBM) [62], that uses perceived susceptibility, severity, barriers and benefits to predict service uptake. The tailoring variables of interventions described in three articles [55], [57] and [60] were based on the Social Cognitive Theory. Also, three articles referred to the Precaution Adoption Process Model [29], [30] and [60]. Furthermore, the Theory of Planned Behavior [60] was referred to. Determinants of this intention are attitude, social influence and perceived behavioral control [62]. One article [40] referred to health behavior theories in general. And, finally, one article [27] mentioned the Extended Parallel Process Model and one [58] the Social Ecological Model to account for the selected tailoring characteristics.

In many articles it remained unclear in which way theory had guided the selection of tailoring variables. However, some studies described which theoretical concepts were chosen from each of the theories [60] and how these were translated in tailoring variables [37]. Articles about interventions tailored on only risk factors mostly did not account for the theory base of the tailoring [25], [35], [36], [42], [51] and [52]. Some of these articles referred to theories on health behavior change in general to explicate the role of risk perception in behavior change processes or to underline the importance of providing a personal risk estimation in modifying risk perception [53] and [56]. One article referred specifically to the Adherence Model to account for the risk factor tailoring [59].

\subsection{Methodological quality}

Although no selection criteria concerning methodological design were included in our search strategy, a large majority of the included articles $(n=37)$ described RCTs. The remaining three articles [25], [52] and [58] described randomized designs with a comparison, but no control group. As indicated in Table 1, the methodological quality assessment revealed two articles of high quality [28] and [45], seven articles of moderate quality and 19 articles of low quality. The criteria for blinding and allocation concealment were most often disobeyed. All studies in the best evidence synthesis were RCTs (see Table 1 for an overview of these studies). Table 3 shows the results.

\section{[TABLE 3]}

Best evidence synthesis for outcome measures of studies on tailored information $(\mathrm{N}=28)^{\mathrm{a}}$.

${ }^{a}$ Number of studies in the table exceeds 28 because several studies reported more than one outcome measure.

\subsection{Outcome measures}

\subsubsection{Knowledge}

Four articles studied an intervention effect on knowledge. Two of these reported on knowledge of breast cancer and mammography. Both articles reported on the same low quality RCT that studied an intervention tailored on risk factors and behavioral constructs. The 24 months follow-up found significantly higher increase in knowledge in intervention compared to control group [29], but no such difference was found at 12 months follow-up [30]. Therefore, we found indicative findings for the effect of this intervention.

One of the four studies assessed knowledge of breast cancer and heredity. This study evaluated an intervention that was tailored based on risk factors, behavioral constructs and information processing constructs [61]. The study was of low quality and found a significant effect. Therefore, we found indicative findings for the effectiveness of this type of intervention. The remaining study assessed knowledge of melanoma. This high quality study found a significant positive effect of an intervention tailored to individuals' risk factors [28]. Therefore, limited evidence was found for the effect of risk factor tailoring. 
Albada, A., Ausems, M.G.E.M., Bensing, J.M., Dulmen, S. van. Tailored information about cancer risk and screening: a systematic review. Patient Education and Counseling: 2009

\subsubsection{Risk perception}

Seven studies assessed perceived risk. Four of these evaluated interventions that were tailored by use of risk factors only. Two interventions provided tailored feedback on susceptibility. Both studies on these interventions reported no significant effect on risk perception, compared to standard information [42] and compared to no intervention [28]. The other two studies, one low [51] and one moderate quality RCT [36], compared an intervention providing tailored risk estimations to standard information. Both studies found a significant positive effect on accuracy of risk perception, suggesting indicative findings for increased effects of risk factor tailoring compared to standard information.

The remaining three articles evaluated interventions that were tailored based on risk factors and behavioral constructs. Two of these studied the same intervention. At 12 months followup this intervention did not significantly effect perceived risk [30], but at 24 months followup there was a significant effect [29]. The third article reported a significant effect on risk perception for respondents overestimating their cancer risk [19]. Thus, two articles reported that an intervention that was tailored based on risk factors and behavioral constructs significantly increased accuracy of perceived risk. This finding is indicative of evidence.

\subsubsection{Screening behavior}

\subsubsection{Breast cancer screening}

Eighteen studies estimated mammography screening rate as adherence to a prescribed screening interval, either based on self-report or provider registration.

Most of these studies ( $\mathrm{n}=11$ of 18 ) evaluated an educational intervention that was tailored based on behavioral constructs only, including pros and cons of behavior and stage of change. As indicated in Table 4, six of these reported a significant effect on mammography adherence [18], [26], [27], [34], [46] and [49]. Clark et al. [18] however, reported an effect only in comparison with usual care; no significant screening increase was found in comparison with standard information. The remaining five studies showed no significant results [33], [41], [43], [45] and [48]. Overall, most of the studies reported that behavioral construct tailored information significantly increased mammography adherence. Therefore, we found indicative findings for increased effects of tailoring based on behavioral constructs compared to a control group receiving no information.

\section{[TABLE 4]}

Three studies described an intervention that was tailored based on risk factors only. Two of these studies evaluated an intervention providing tailored risk factor feedback and revealed no significant effects on screening behavior [35] and [38]. One of these studies even found personalized information superior, since the group receiving personalized information had a higher mammography rate than the group receiving information that was additionally tailored [38]. One study found a significant increase in the group receiving tailored risk factor feedback and relative risk estimation compared to the control group [59]. Thus, insufficient evidence was found for the effect of risk factor tailoring on mammography use.

Three articles described an intervention tailored based on both behavioral constructs and risk factors [20], [29] and [30]. None of these reported significant effects on screening behavior. Therefore, there is no evidence for this type of tailoring.

Only one article evaluated an intervention that was tailored based on behavioral as well as cultural constructs [40]. This moderate quality study found significant effects. Thus, there are indicative findings that information tailored on behavioral as well as cultural constructs increases mammography screening rates. 
Albada, A., Ausems, M.G.E.M., Bensing, J.M., Dulmen, S. van. Tailored information about cancer risk and screening: a systematic review. Patient Education and Counseling: 2009

\subsubsection{Cervical cancer screening}

Three studies, all low quality RCTs, reported on pap-test use. Two of these studied an intervention tailored on behavioral constructs. Both found no significant effects $(\mathrm{p}<.05)$ [20] M.W. Kreuter and V.J. Strecher, Do tailored behavior change messages enhance the effectiveness of health risk appraisal? Results from a randomized trial, Health Educ Res 11 (1996), pp. 97-105. Full Text via CrossRef | View Record in Scopus | Cited By in Scopus (105)[20] and [48]. Therefore, there is no evidence for effects on pap-test use of materials tailored on behavioral constructs. One study evaluated materials that were tailored based on risk factors and found a negative effect on pap-test use [38]. Therefore, there is also no evidence for interventions tailored based on risk factors.

\subsubsection{Colorectal cancer screening}

Two studies focused on fecal occult blood test use as screening for colorectal cancer [53] and [54]. First, Lipkus and Klein [53] found that an intervention providing risk factor feedback did not significantly increase screening rate. Second, Marcus et al. [54] studied an intervention that was additionally tailored based on behavioral constructs. This study showed a significant increase in screening uptake for the group receiving four tailored booklets compared to a control group receiving one standard booklet. The group receiving one tailored booklet did not show more screening uptake than the control group. Thus, no studies revealed significant effects of tailored versus comparable standard information or usual care. Therefore, there is no evidence for the effect of tailored interventions on colorectal cancer screening uptake.

\subsubsection{Skin cancer screening}

One study evaluated a multimedia intervention about skin cancer for effects on mole checking. This intervention provided standard information about dangers of sun exposure, possibilities for risk reduction and mole checking and risk factor tailored feedback of relative susceptibility for skin cancer [28]. This high quality RCT showed a significant intervention effect on mole checking, suggesting limited evidence for risk factor tailoring on skin selfexamination.

\section{DISCUSSION AND CONCLUSION}

\subsection{Discussion}

Whereas evidence for the effectiveness of interventions providing tailored information on several preventive health behaviors was already established, this review adds indications for similar evidence for tailored information about cancer risk and screening. Noar et al. [11] found that tailored interventions outperformed non-tailored comparison messages in effects on health behavior. The current review revealed indications for the added value of tailored above standard information with respect to increase in knowledge and realistic risk perceptions. However, as opposed to Noar et al. [11] we found no indications for added value of tailored above standard information for the effect on cancer screening behavior, which might be considered a more distal outcome. This can partly be explained through strict Cochrane quality criteria that we applied, as illustrated below, and partly by insignificant findings that meta-analyses include and best evidence syntheses do not take into account. We found effects on screening adherence of information tailored on behavioral constructs compared to no information. Although a majority of studies ( $n=6$ of 11) focusing on these interventions compared to usual care or no intervention reported significant positive effects, our best evidence synthesis found only indications for evidence. This is due to the low methodological quality of these RCTs, often disregarding criteria for allocation concealment and intention-to-treat analysis. However, the minimal checklist for assessing quality of RCTs used in this review is strict. It includes criteria for blinding that are challenging in studies of 
information provision, because when a patient is informed about the study he might recognize the intervention. Thus, although the positive results of the majority of studies indicate some evidence, studies of better methodological quality are needed.

The evidence base suggested in this review is built primarily on intervention studies using a behavioral construct approach. This type of tailoring relies on well-established theories of health behavior change, such as the Transtheoretical Model and the Health Belief Model, and uses variables like stage of change, self-efficacy and intentions [63] to adapt messages or to provide tailored feedback on psychological or behavioral state. This review suggests that these interventions with the most solid theory base are most effective. However, interventions aiming at increase of realistic risk perception or knowledge might need theory specifically about risk perception.

Less evidence was found for the effect on cancer screening of interventions providing information tailored on risk factors only. There was limited evidence that tailoring messages effected mole checking, but no evidence that tailoring messages affected breast, cervical or colon cancer screening. This is consistent with findings from early reviews of Health Risk Appraisals that could not establish effectiveness of interventions providing personal risk estimation [66] and [67]. It has been stated that programs aiming to increase screening behavior should provide more than risk information. Increasing risk awareness is a first step, but often insufficient in persuading people to take precautionary action [20] and [68]. The two studies that found significant effects of risk factor tailoring evaluated an intervention providing elaborate information that not only included personalized risk estimation, but also generic behavior change information [28] and [59]. The studies that did not find effects of risk factor tailoring evaluated invitation letters without generic information about how to change behavior [35], [38] and [53]. Thus, although there is more evidence for interventions tailored on behavioral determinants, the addition of generic information to tailored risk factor interventions might also increase effects on cancer screening uptake.

Few studied interventions were tailored by use of information processing or cultural constructs. One study evaluated an intervention that was tailored to information needs [61]. Three studies, that were excluded because the interventions were tailored on only one variable, also used a tailoring variable related to the way in which individuals process information: coping style, locus of control beliefs and need for cognition, respectively [69], [70] and [71]. Because of individual differences in information processing, tailoring based on variables related to these processes appears an interesting area for further research. Cultural constructs, as used in targeted interventions, were applied in one studied intervention [40] and seem promising tailoring variables when respondents have different cultural backgrounds.

Noar et al. [11] found a trend that tailoring based on more than one construct increased effectiveness. A combination of the tailoring characteristics behavior, theoretical concepts from behavior change theories and demographics seemed most effective. Our review did not find evidence for increased effectiveness of tailoring based on both behavioral constructs and risk factors. Information processing and cultural constructs were each used in only one study, in combination with at least behavioral constructs. Both these interventions showed significant positive effects.

Although we established evidence for tailored information about cancer risk and screening, there is room for improvement of the theory base. Noar et al. [11] noticed that often only parts of a theory are used and combined. In addition, we found that articles contained little information about intervention development, such as theoretical concepts, their relation to theory and translation into text adaptations. All articles described tailoring variables, but the manner in which information was adapted to these variables was often implicit. Furthermore, the working mechanism of tailoring is often explained through ELM. However, both Dijkstra [64] and Hawkins et al. [65] argued that tailoring by adapting information or by providing feedback relies on different psychological processes. Whereas feedback is presented to be perceived as tailored to the individual, adapted information might seem generic to the reader. 
Thus, enhanced effectiveness of adapted information can be explained by the ELM, the effectiveness of feedback can possibly be guided by personalization effects, such as selfreferent encoding.

This study has several limitations. First, while every effort was made to conduct a comprehensive, thorough review, the reported effects may have been exaggerated through publication bias. Second, it was difficult to compare the included studies, because of heterogeneity. Therefore, a best evidence synthesis was conducted instead of a metaanalysis. Best evidence synthesis does not consider insignificant results or weights of studies and is thus less sensitive than meta-analysis. Third, in our quality assessment we relied on information about the methodology as reported in the articles. Information about allocation concealment, blinding and use of intention-to-treat analysis was often missing. We then scored these items as unclear, without contacting authors for verification. If an article did not explicitly refer to another article for explanation of the study procedure, we judged the quality of the possibly related articles independent from each other. Fourth, since a majority of the studies only included female respondents, we are unsure whether tailored interventions in cancer risk communication possess equal effectiveness on male respondents, though Noar et al. [11] found no significant impact of gender on effect size. Finally, process measures, such as delivery rates or respondents' reading time, were mostly missing or poorly described. Future studies using computer-delivered interventions could easily integrate these measures.

\subsection{Conclusion}

Numerous interventions providing tailored information about cancer risk or screening, delivered by print or computer, have been studied in the last decade. Most of these interventions aimed to promote cancer screening and tailored information to behavioral constructs based on the TTM or the HBM. Although many interventions tailored information by use of behavioral constructs, we found only increased effects compared to generic information on cancer risk perception and knowledge of breast cancer. We found effects of behavioral construct tailored information on mammography uptake only compared to control groups receiving no intervention. In addition, we found increased effects on cancer risk perception of risk factor tailored information compared to standard information. Lastly, this review established limited evidence for the effect of a website tailored on risk factors, knowledge of melanoma and mole checking compared to no intervention.

\subsection{Practice implications}

As consultation time is scarce, interventions have been developed to increase cancer screening uptake without needing physician involvement. Mostly these are letters, booklets, magazines or computer programs providing information about cancer risk and screening. Based on this review we conclude that these interventions might be more effective when providing individually tailored as opposed to general information, i.e., providing information adapted to individual characteristics assessed in a print or digital questionnaire. Thus after a participant has completed a questionnaire, information is adjusted to individual characteristics by use of 'if-then' rules. For example, a multimedia intervention about skin cancer provided, next to standard information, feedback of relative susceptibility based on risk factors for skin cancer, such as skin characteristics and sunburn history. This intervention increased knowledge of melanoma and respondents' mole checking [28]. Other interventions tailor based on behavioral constructs, i.e., behavior change variables. For example, an interactive multimedia computer program aiming to improve colorectal cancer screening uptake in a healthy population, provided respondents with tailored information with explicit reference and response to their answers to questions about self-efficacy and perceived barriers for screening [37].

This review indicates that tailoring based on behavioral constructs, e.g., attitudes, intentions, stage of change, seems more effective than tailoring based on risk factors only, e.g., family history. It might be advisable to use behavior change variables as well as risk factors and possibly other variables, such as cultural characteristics. Theory-guided choice of 
Albada, A., Ausems, M.G.E.M., Bensing, J.M., Dulmen, S. van. Tailored information about cancer risk and screening: a systematic review. Patient Education and Counseling: 2009

tailoring variables and type of tailoring possibly increases effectiveness and facilitates future identification of effective theoretical concepts. Whereas current tailored interventions mostly aim at health behavior change of healthy population individuals, this technique might also be promising to increase knowledge, accurate risk perception and screening uptake of individuals at increased cancer risk.

\section{ACKNOWLEDGEMENT}

This study was supported by a grant from the Dutch Cancer Society (Nivel 2006-3469).

\section{[APPENDIX A]}

\section{[APPENDIX B]}

\section{REFERENCES}

[1] B.K. Rimer and B. Glassman, Is there use for tailored print communications in cancer risk communication?, J Natl Cancer Inst Monogr 25 (1999), pp. 140-148.

[2] N.D. Weinstein, The precaution adoption process, Health Psychol 7 (1988), pp. 355-386.

[3] J.L. Bottorff, P.A. Ratner, J.L. Johnson, C.Y. Lovato and S.A. Joab, Communicating cancer risk information: the challenges of uncertainty, Patient Educ Couns 33 (1998), pp. 67-81.

[4] P. Hopwood, Psychosocial aspects of risk communication and mutation testing in familial breast-ovarian cancer, Curr Opin Oncol 17 (2005), pp. 340-344.

[5] M. Gerrard, F.X. Gibbons and M. Reis-Bergan, The effect of risk communication on risk perceptions: the significance of individual differences, J Natl Cancer Inst Monogr 25 (1999), pp. 94-100.

[6] M. Kreuter, D.W. Farrel and L. Olevitch, Tailoring health messages, customizing communication with computer technology, Lawrence Erlbaum Associates, Mahwah (2000).

[7] M.W. Kreuter, V.J. Strecher and B. Glassman, One size does not fit all: the case for tailoring print materials, Ann Behav Med 21 (1999), pp. 276-283.

[8] S.B. Bental, A. Cawsey and R. Jones, Patient information systems that tailor to the individual, Patient Educ Couns 36 (1999), pp. 171-180.

[9] R. Petty and J. Cacioppo, The Elaboration Likelihood Model of persuasion, Adv Exp Soc Psychol 19 (1986), pp. 123-205.

[10] R.A. Ruiter, L.T. Kessels, B.M. Jansma and J. Brug, Increased attention for computertailored health communications: an event-related potential study, Health Psychol 25 (2006), pp. 300-306.

[11] S.M. Noar, C.N. Benac and M.S. Harris, Does tailoring matter? Meta-analytic review of tailored print health behavior change interventions, Psych Bull 133 (2007), pp. 673-693.

[12] V.J. Strecher, Computer-tailored smoking cessation materials: a review and discussion, Patient Educ Couns 36 (1999), pp. 107-117.

[13] S.T. Walters, J.A. Wright and R. Shegog, A review of computer and Internet-based interventions for smoking behavior, Addict behav 31 (2006), pp. 264-277.

[14] J. Brug, M. Campbell and P. van Assema, The application and impact of computergenerated personalized nutrition education: a review of the literature, Patient Educ Couns 36 (1999), pp. 145-156.

[15] W. Kroeze, A. Werkman and J. Brug, A systematic review of randomized trials on the effectiveness of computer-tailored education on physical activity and dietary behaviors, Ann Behav Med 31 (2006), pp. 205-223. [16] D. Revere and P.J. Dunbar, Review of computer-generated outpatient health behavior interventions: clinical encounters "in absentia", J Am Med Inform Assoc 8 (2001), pp. 62-79.

[17] , Cochrane handbook for systematic reviews of interventions 4.2.6. In: J.P.T. Higgins and S. Green, Editors, The Cochrane library, John Wiley \& Sons, Issue 4 Chichester (2006). 
Albada, A., Ausems, M.G.E.M., Bensing, J.M., Dulmen, S. van. Tailored information about cancer risk and screening: a systematic review. Patient Education and Counseling: 2009

[18] M.A. Clark, W. Rakowski, B. Ehrich, B.K. Rimer, W.F. Velicer, C.E. Dube, D.N. Pearlman, K.K. Peterson and M. Goldstein, The effect of a stage-matched and tailored intervention on repeat mammography, Am J Prev Med 22 (2002), pp. 1-7.

[19] M.W. Kreuter and V.J. Strecher, Changing inaccurate perceptions of health risk: results from a randomized trial, Health Psychol 14 (1995), pp. 56-63.

[20] M.W. Kreuter and V.J. Strecher, Do tailored behavior change messages enhance the effectiveness of health risk appraisal? Results from a randomized trial, Health Educ Res 11 (1996), pp. 97-105. [21] Ryan R, Broclain D, Horey D, Oliver S, Prictor M. Study quality guide. Cochrane Consumers and Communication review group; 2007.

[22] M. Van Tulder, A. Furlan, C. Bombardier and L. Bouter, Updated method guidelines for systematic reviews in the Cochrane collaboration back review group, Spine 28 (2003), pp. 1290-1299.

[23] N. Van der Meulen, J. Jansen, S. Van Dulmen, J. Bensing and J. van Weert, Interventions to improve recall of medical information in cancer patients: a systematic review of the literature, Psycho-oncology 17 (2008), pp. 857-868.

[24] E.M. Steultjens, J. Dekker, L.M. Bouter, D. van Schaardenburg, M.A. van Kuyk and C.H. van den Ende, Occupational therapy for rheumatoid arthritis, Cochrane Db Syst Rev (2004), p. CD003114.

[25] A.C. Marcus, L.A. Crane, C.P. Kaplan, A.E. Reading, E. Savage, J. Gunning, G. Bernstein and J.S. Berek, Improving adherence to screening follow-up among women with abnormal Pap smears: results from a large clinic-based trial of three intervention strategies, Med Care 30 (1992), pp. 216-230.

[26] C.S. Skinner, S.C. Kobrin, P.O. Monahan, J. Daggy, U. Menon, H.S. Todora and V.L. Champion, Tailored interventions for screening mammography among a sample of initially non-adherent women: when is a booster dose important?, Patient Educ Couns 65 (2007), pp. 87-94.

[27] V. Champion, C.S. Skinner, S. Hui, P. Monahan, B. Juliar, J. Daggy and U. Menon, The effect of telephone versus print tailoring for mammography adherence, Patient Educ Couns 65 (2007), pp. 416-423.

[28] C. Glazebrook, P. Garrud, A. Avery, C. Coupland and H. Williams, Impact of a multimedia intervention "Skinsafe" on patients' knowledge and protective behaviors, Prev Med 42 (2006), pp. 449-454.

[29] B.K. Rimer, S. Halabi, S.C. Sugg, I.M. Lipkus, T.S. Strigo, E.B. Kaplan and G.P. Samsa, Effects of a mammography decision-making intervention at 12 and 24 months, Am J Prev Med 22 (2002), pp. 247-257.

[30] B.K. Rimer, S. Halabi, S.C. Sugg, E.B. Kaplan, Y. Crawford, G.P. Samsa, T.S. Strigo and I.M. Lipkus, The short-term impact of tailored mammography decision-making interventions, Patient Educ Couns 43 (2001), pp. 269-285.

[31] B. Valanis, E.E. Whitlock, J. Mullooly, T. Vogt, S. Smith, C. Chen and R.E. Glasgow, Screening rarely screened women: time-to-service and 24-month outcomes of tailored interventions, Prev Med 37 (2003), pp. 442-450.

[32] B.G. Valanis, R.E. Glasgow, J. Mullooly, T.M. Vogt, E.P. Whitlock, S.M. Boles, K.S. Smith and T.M. Kimes, Screening HMO women overdue for both mammograms and pap tests, Prev Med 34 (2002), pp. 40-50.

[33] V.L. Champion, J.K. Springston, T.W. Zollinger, Saywell Jr., P.O. Monahan, Q. Zhao and K.M. Russell, Comparison of three interventions to increase mammography screening in low income African American women, Cancer Detect Prev 30 (2006), pp. 535-544. [34] V.L. Champion, C.S. Skinner, U. Menon, R. Seshadri, D.C. Anzalone and S.M. Rawl, Comparisons of tailored mammography interventions at two months postintervention, Ann Behav Med 24 (2002), pp. 211-218.

[35] S.J. Curry, S.H. Taplin, C. Anderman, W.E. Barlow and C. McBride, A randomized trial of the impact of risk assessment and feedback on participation in mammography screening,Prev Med 22 (1993), pp. 350-360.

[36] K.M. Emmons, M. Wong, E. Puleo, N. Weinstein, R. Fletcher and G. Colditz, Tailored computer-based cancer risk communication: correcting colorectal cancer risk perception, J Health Commun 9 (2004), pp. 127-141.

[37] A. Jerant, R.L. Kravitz, M. Rooney, S. Amerson, M. Kreuter and P. Franks, Effects of a tailored interactive multimedia computer program on determinants of colorectal cancer 
Albada, A., Ausems, M.G.E.M., Bensing, J.M., Dulmen, S. van. Tailored information about cancer risk and screening: a systematic review. Patient Education and Counseling: 2009

screening: a randomized controlled pilot study in physician offices, Patient Educ Couns 66 (2006), pp. 67-74.

[38] M.L. Jibaja-Weiss, R.J. Volk, P. Kingery, Q.W. Smith and J.D. Holcomb, Tailored messages for breast and cervical cancer screening of low-income and minority women using medical records data, Patient Educ Couns 50 (2003), pp. 123-132.

[39] M.L. Jibaja, P. Kingery, N.E. Neff, Q. Smith, J. Bowman and J.D. Holcomb, Tailored, interactive soap operas for breast cancer education of high-risk Hispanic women, J Cancer Educ 15 (2000), pp. 237-242.

[40] M.W. Kreuter, C. Sugg-Skinner, C.L. Holt, E.M. Clark, D. Haire-Joshu, Q. Fu, A.C. Booker, K. Steger-May and D. Bucholtz, Cultural tailoring for mammography and fruit and vegetable intake among low-income African-American women in urban public health centers, Prev Med 41 (2005), pp. 53-62.

[41] I.M. Lipkus, B.K. Rimer, S. Halabi and T.S. Strigo, Can tailored interventions increase mammography use among HMO women?, Am J Prev Med 18 (2000), pp. 1-10.

[42] C.M. McBride, G. Bepler, I.M. Lipkus, P. Lyna, G. Samsa, J. Albright, S. Datta and B.K. Rimer, Incorporating genetic susceptibility feedback into a smoking cessation program for African-American smokers with low income, Cancer Epidemiol Biomarkers Prev 11 (2002), pp. 521-528.

[43] K.D. McCaul and K.S. Wold, The effects of mailed reminders and tailored messages on mammography screening, J Commun Health 27 (2002), pp. 181-190.

[44] R.E. Myers, G.W. Chodak, T.A. Wolf, D.Y. Burgh, G.T. McGrory, S.M. Marcus, J.A. Diehl and $\mathrm{M}$. Williams, Adherence by African American men to prostate cancer education and early detection, Cancer 86 (1999), pp. 88-104.

[45] J.O. Prochaska, W.F. Velicer, C. Redding, J.S. Rossi, M. Goldstein, J. DePue, G.W. Greene, S.R. Rossi, X. Sun, J.L. Fava, R. Laforge, W. Rakowski and B.A. Plummer, Stagebased expert systems to guide a population of primary care patients to quit smoking, eat healthier, prevent skin cancer, and receive regular mammograms, Prev Med 41 (2005), pp. 406-416

[46] W. Rakowski, B. Ehrich, M.G. Goldstein, B.K. Rimer, D.N. Pearlman, M.A. Clark, W.F. Velicer and $\mathrm{H}$. Woolverton, Increasing mammography among women aged $40-74$ by use of a stage-matched, tailored intervention, Prev Med 27 (1998), pp. 748-756.

[47] W. Rakowski, I.M. Lipkus, M.A. Clark, B.K. Rimer, B. Ehrich, P.R. Lyna and P.J. Kornguth, Reminder letter, tailored stepped-care, and self-choice comparison for repeat mammography, Am J Prev Med 25 (2003), pp. 308-314.

[48] B.K. Rimer, M. Conaway, P. Lyna, B. Glassman, K.S. Yarnall, I. Lipkus and L.T. Barber, The impact of tailored interventions on a community health center population, Patient Educ Couns 37 (1999), pp. 125-140.

[49] R.M. Saywell Jr., V.L. Champion, C.S. Skinner, U. Menon and J. Daggy, A costeffectiveness comparison of three tailored interventions to increase mammography screening, J Women Health 13 (2004), pp. 909-918.

[50] C.S. Skinner, V.J. Strecher and H. Hospers, Physicians' recommendations for mammography: do tailored messages make a difference?, Am J Public Health 84 (1994), pp. 43-49.

[51] N.D. Weinstein, K. Atwood, E. Puleo, R. Fletcher, G. Colditz and K.M. Emmons, Colon cancer: risk perceptions and risk communication, J Health Commun 9 (2004), pp. 53-65.

[52] D. Smit West, P. Greene, L. Pulley, P. Kratt, S. Gore, H. Weiss and N. Siegfried, Stepped-care, community clinic interventions to promote mammography use among lowincome rural African American women, Health Educ Behav 31 (2004), pp. 29S-44S.

[53] I.M. Lipkus and W.M. Klein, Effects of communicating social comparison information on risk perceptions for colorectal cancer, J Health Commun 11 (2006), pp. 391-407.

[54] A.C. Marcus, M. Mason, P. Wolfe, B.K. Rimer, I. Lipkus, V. Strecher, R. Warneke, M.E. Morra, A.R. Allen, S.W. Davis, A. Gaier, C. Graves, K. Julesberg, L. Nguyen, R. Perocchia, J.B. Speyer, D. Wagner, C. Thomsen and M.A. Bright, The efficacy of tailored print materials in promoting colorectal cancer screening: results from a randomized trial involving callers to the National Cancer Institute's Cancer Information Service, J Health Commun 10 (2005), pp. 83-104.

[55] M.K. Campbell, I. Tessaro, B. DeVellis, S. Benedict, K. Kelsey, L. Belton and A. Sanhueza, Effects of a tailored health promotion program for female blue-collar workers: 
Albada, A., Ausems, M.G.E.M., Bensing, J.M., Dulmen, S. van. Tailored information about cancer risk and screening: a systematic review. Patient Education and Counseling: 2009

health works for women, Prev Med 34 (2002), pp. 313-323. [56] I.M. Lipkus, C.S. Skinner, J. Dement, L. Pompeii, B. Moser, G.P. Samsa and D. Ransohoff, Increasing colorectal cancer screening among individuals in the carpentry trade: test of risk communication interventions, Prev Med 40 (2005), pp. 489-501.

[57] M.K. Campbell, A. James, M.A. Hudson, C. Carr, E. Jackson, V. Oakes, S. Demissie, D. Farrell and I. Tessaro, Improving multiple behaviors for colorectal cancer prevention among African American church members, Health Psychol 23 (2004), pp. 492-502.

[58] K.M. Emmons, E. Puleo, E. Park, E.R. Gritz, R.M. Butterfield, J.C. Weeks, A. Mertens and F.P. Li, Peer-delivered smoking counseling for childhood cancer survivors increases rate of cessation: the partnership for health study, J Clin Oncol 23 (2005), pp. 6516-6523.

[59] R. Bastani, A.E. Maxwell, C. Bradford, I.P. Das and K.X. Yan, Tailored risk notification for women with a family history of breast cancer, Prev Med 29 (1999), pp. 355-364. [60] A.C. Geller, K.M. Emmons, D.R. Brooks, C. Powers, Z. Zhang, H.K. Koh, T. Heeren, A.J. Sober, F. Li and B.A. Gilchrest, A randomized trial to improve early detection and prevention practices among siblings of melanoma patients, Cancer 107 (2006), pp. 806814.

[61] C.S. Skinner, J.M. Schildkraut, D. Berry, B. Calingaert, P.K. Marcom, J. Sugarman, E.P. Winer, J.D. Iglehart, P.A. Futreal and B.K. Rimer, Pre-counseling education materials for BRCA testing: does tailoring make a difference?, Genet Test 6 (2002), pp. 93-105.

[62] M.A. Koelen and A.W. Van den Ban, Health education and health promotion, Wageningen Academic Publishers, Wageningen (2004).

[63] M.W. Kreuter, C.S. Skinner, K. Steger-May, C.L. Holt, D.C. Bucholtz, E.M. Clark and D. Haire-Joshu, Responses to behaviorally vs culturally tailored cancer communication among African American women, Am J Health Behav 28 (2004), pp. 195-207.

[64] A. Dijkstra, The psychology of tailoring. Ingredients in computer-tailored persuasion, Soc Pers Psychol Compass 2 (2008), pp. 765-784.

[65] R.P. Hawkins, M. Kreuter, K. Resnicow, M. Fishbein and A. Dijkstra, Understanding tailoring in communication about health, Health Educ Res 23 (2008), pp. 454-466.

[66] V.J. Schoenbach, Health risk appraisal: review of evidence for effectiveness, Health Serv Res 22 (1987), pp. 553-580.

[67] E.H. Wagner, An assessment of health hazard/health risk appraisal, Am J Public Health 72 (1982), pp. 347-352.

[68] J. Van der Pligt, Cognition, and affect in risk perception and risky decision-making. In: C. Von Hofsten and L. Bäckman, Editors, Psychology at the turn of the millennium, social, developmental, and clinical perspectives, Psychology Press, Hove (2002), pp. 247-270.

[69] P. Williams-Piehota, T.R. Schneider, J. Pizarro, L. Mowad and P. Salovey, Matching health messages to information-processing styles: need for cognition and mammography utilization, Health Commun 15 (2003), pp. 375-392.

[70] P. Williams-Piehota, J. Pizarro, T.R. Schneider, L. Mowad and P. Salovey, Matching health messages to monitor-blunter coping styles to motivate screening mammography, Health Psychol 24 (2005), pp. 58-67.

[71] P. Williams-Piehota, T.R. Schneider, J. Pizarro, L. Mowad and P. Salovey, Matching health messages to health locus of control beliefs for promoting mammography utilization, Psychol Health 19 (2004), pp. 407-423.

Corresponding author at: NIVEL (Netherlands Institute for Health Services Research), P.O. Box 1568, 3500 BN Utrecht, The Netherlands. Tel.: +31 0302729 638; fax: +31 0302729 729. 
Albada, A., Ausems, M.G.E.M., Bensing, J.M., Dulmen, S. van. Tailored information about cancer risk and screening: a systematic review. Patient Education and Counseling: 2009

FIGURES, TABLES AND APPENDIX

\section{FIGURE 1}

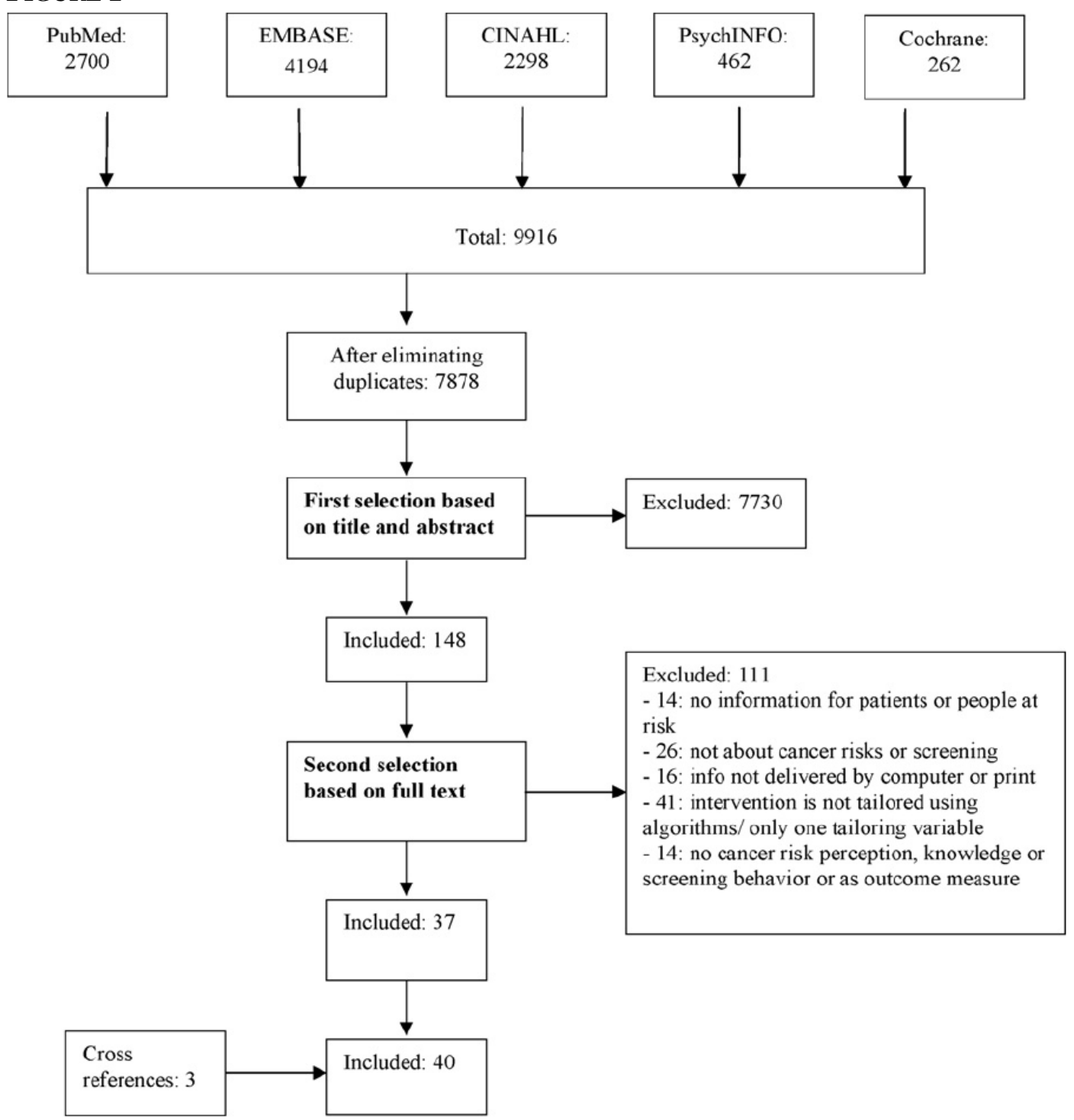

Fig. 1. Flowchart of the inclusion procedure. 
Characteristics and effects of RCTs comparing tailored information vs. non-tailored information or usual care

\begin{tabular}{|c|c|c|c|c|c|c|c|}
\hline $\begin{array}{l}\text { Study: country: } \\
\text { quality }\end{array}$ & Intervention groups & $\begin{array}{l}\text { Tailoring characteristics: } \\
\text { theory-based }\end{array}$ & Recruitment & $\begin{array}{l}\text { Participants (gender, age. } \\
\text { disease status, ethnicity. } \\
\text { health care setting)" }\end{array}$ & $\begin{array}{l}N^{b} \text { : response drop } \\
\text { out': fulfilled } \\
\text { quality criteriac }\end{array}$ & $\begin{array}{l}\text { Outcome } \\
\text { measures }\end{array}$ & $\begin{array}{l}\text { Significant effects for } \\
\text { all study } \\
\text { participants }(p<.05)\end{array}$ \\
\hline $\begin{array}{l}\text { Bastani et al. [59]: } \\
\text { USA: Iow quality }\end{array}$ & $\begin{array}{l}\text { (1) tailored risk } \\
\text { notification letter with a } \\
\text { standard educational } \\
\text { booklet, notepad and } \\
\text { bookmark: (2) standard } \\
\text { materials to increase } \\
\text { mammo use }\end{array}$ & $\begin{array}{l}\text { - BC risk factors } \\
\text { - BC risk status: } \\
\text { Adherence Model }\end{array}$ & $\begin{array}{l}\text { A random sample of BC } \\
\text { cases were asked info } \\
\text { about female first degree } \\
\text { relatives, which received } \\
\text { info and were contacted } \\
\text { by phone }\end{array}$ & $\begin{array}{l}1000 \text { female; } x=51 \text { yr; } \\
\text { first degree relatives of } \\
\text { BC patients }\end{array}$ & $\begin{array}{l}902 ; 66 \% ; 16 \% ; \\
1 \text { and } 7\end{array}$ & $\begin{array}{l}\text { - Mammo rate } \\
\text { (self-reported) }\end{array}$ & $\begin{array}{l}\text { Higher increase in } \\
\text { mammo rate }(10.2 \%) \\
\text { in group } 1 \text { than group } \\
2(2.5 \%)(p=.05) \text {. } \\
(\mathrm{OR}-1.45, p-.3)\end{array}$ \\
\hline $\begin{array}{l}\text { Champion et al. |27]: } \\
\text { USA: low quality }\end{array}$ & $\begin{array}{l}\text { (1) Tailored print } \\
\text { materials: (2) tailored tel } \\
\text { counseling: (3) tailored } \\
\text { tel counseling and print: } \\
\text { (4) uc (no intervention): to } \\
\text { promote mammo adherence }\end{array}$ & $\begin{array}{l}\text { Perceived BC risk, } \\
\text { benefits, barriers. } \\
\text { self-efficacy, knowledge } \\
\text { of mammo procedures: } \\
\text { TTM \& HBM \& EPPM }\end{array}$ & $\begin{array}{l}\text { A university-affiliated } \\
\text { medicine clinic and an } \\
\text { HMO send eligible patients } \\
\text { a letter and study brochure }\end{array}$ & $\begin{array}{l}\text { 100\% female: } x-66 \text { yr: } \\
\text { non-affected registered } \\
\text { patients }\end{array}$ & 1244: 1 & $\begin{array}{l}\text { - Mammo use at } \\
4 \text { mo by medical } \\
\text { record } \\
\text { - Mammo use by } \\
\text { self-report } \\
\text { - Stage of adoption }\end{array}$ & $\begin{array}{l}2 \text { mo post-intervention } \\
\text { effect on forward stage } \\
\text { movement of the } \\
\text { participants receiving } \\
\text { tailored print compared } \\
\text { to uc ( (OR }-1.55 \text {. } \\
p-.015 \text { ) and } 4 \text { mo } \\
\text { post-intervention } \\
\text { increase in manmo } \\
\text { adherence (OR }=1.07 \text {, } \\
p-.006 \text { ) }\end{array}$ \\
\hline $\begin{array}{l}\text { Champion et al. [33]: } \\
\text { USA; low quality }\end{array}$ & $\begin{array}{l}\text { (1) Pamphlet only (not } \\
\text { tailored): (2) culturally } \\
\text { appropriate video: (3) } \\
\text { tailored interactive computer } \\
\text { intervention: to increase } \\
\text { mammo screening }\end{array}$ & $\begin{array}{l}\text { - Knowledge } \\
\text { - Health beliefs about BC } \\
\text { - Mammo screening: } \\
\text { TTM \& HBM }\end{array}$ & $\begin{array}{l}\text { Approached in a multi-service } \\
\text { centre, an African American } \\
\text { convention or a general } \\
\text { medicine clinic serving } \\
\text { low-income clients }\end{array}$ & $\begin{array}{l}100 \% \text { female: } x(S D)=51(9) \text {; } \\
\text { low-income; African } \\
\text { American }\end{array}$ & 344: $70 \%: 1$ & $\begin{array}{l}\text {-Adherence to } \\
\text { mammmo } \\
\text {-Mammo stage of } \\
\text { readiness }\end{array}$ & $\begin{array}{l}\text { tailored computer } \\
\text { program group had } \\
\text { most forward movement } \\
\text { in mammos stage } \\
\text { compared to pamphlet } \\
\text { only group ( } 52 \% \text { vs. 36\%. } \\
p<.05 \text { ). Likelihood of } \\
\text { adherence was twice } \\
\text { as high for the computer } \\
\text { as the video group } \\
\text { (OR }=2.05, p<.05 \text { ) }\end{array}$ \\
\hline $\begin{array}{l}\text { Champion et al. [34]; } \\
\text { USA; low quality }\end{array}$ & See Champion, 2007 & See Champion, 2007 & See Champion, 2007 & $100 \%$ female; $X-67 \mathrm{yr}$ & 1367: 1 & - Mammo screening & $\begin{array}{l}2 \text { mo post-intervention } \\
\text { groups } 1-3 \text { have higher } \\
\text { mammo rate than UC } \\
\text { group (OR }=2.16 \text { for tel } \\
\text { plus print, } 1.72 \text { for print } \\
\text { only, } 1.66 \text { tel only) }\end{array}$ \\
\hline $\begin{array}{l}\text { Clark et al. [18]: USA: } \\
\text { moderate quality }\end{array}$ & $\begin{array}{l}\text { (1) Stage-matched tailored } \\
\text { materials; (2) UC (active } \\
\text { reminder); ( } 3 \text { standard } \\
\text { materials to promote } \\
\text { mammo screening }\end{array}$ & $\begin{array}{l}\text { - Stage of mammo } \\
\text { adoption } \\
\text { - Pros and cons of } \\
\text { screening: TTM }\end{array}$ & $\begin{array}{l}\text { random selection of eligible } \\
\text { women who contacted } \\
\text { HMO prior } 8 \mathrm{mo}\end{array}$ & $100 \%$ female & $\begin{array}{l}\text { 1324: 74\%: } 29 \%: \\
1,6 \text { and } 7\end{array}$ & - Mammo & $\begin{array}{l}\text { Tailored info group was } \\
\text { more likely to obtain } \\
\text { repeat screening } \\
\text { mammo than UC group } \\
\text { (44.2 vs. } 35.8 \% \text {, adjusted } \\
\text { rate ratio } 1.29 p<.05 \text { ) }\end{array}$ \\
\hline $\begin{array}{l}\text { Curry et al. }[35] \text { : USA: } \\
\text { moderate quality }\end{array}$ & $\begin{array}{l}\text { (1) Tailored risk invitation; } \\
\text { (2) general risk invitation; } \\
\text { (3) generic invitation for } \\
\text { mammo screening }\end{array}$ & $\begin{array}{l}\text { - Age } \\
\text { - Other self-reported } \\
\text { BC risk factors }\end{array}$ & $\begin{array}{l}\text { HMO registered women } \\
\text { were sent a questionnaire } \\
\text { or introduction letter }\end{array}$ & $\begin{array}{l}100 \% \text { female; } x=61 \mathrm{yr} \\
\text { HMO members }\end{array}$ & $80 \%: 1,6$ and 7 & - Mammo screening & None \\
\hline
\end{tabular}




\begin{tabular}{|c|c|c|c|c|c|c|c|}
\hline $\begin{array}{l}\text { Emmons et al. [36]: } \\
\text { USA: moderate } \\
\text { quality }\end{array}$ & $\begin{array}{l}\text { (1) Computer program } \\
\text { providing colon cancer } \\
\text { risk information; }(2) 1 \text { with } \\
\text { personalized absolute risk } \\
\text { estimation and manipulation } \\
\text { of risk factors; ( } 32 \text { 2 with } \\
\text { personalized relative risk } \\
\text { estimation }\end{array}$ & $\begin{array}{l}\text { Risk factors for colon } \\
\text { cancer: } \\
\text { - Family history } \\
\text { - Weight } \\
\text { - Diet } \\
\text { - Physical activity } \\
\text { - Colorectal cancer } \\
\text { screening }\end{array}$ & $\begin{array}{l}\text { Patients with scheduled } \\
\text { routine health care or } \\
\text { non-urgent care visits at } \\
\text { two primary care practices } \\
\text { between } 40 \text { and } 70 \text { yr of } \\
\text { age were sent an introductory } \\
\text { letter followed by a tel call }\end{array}$ & $\begin{array}{l}55 \% \text { female; } \bar{x}(\mathrm{SD})- \\
55(8) \text { yr: age } 40-70 \mathrm{yr}: \\
\text { non-affected primary } \\
\text { care patients being }\end{array}$ & $\begin{array}{l}353 ; 25 \% ; \mathrm{NA} \\
1,2 \text { and } 7\end{array}$ & $\begin{array}{l}\text { - Accuracy of } \\
\text { perceived risk }\end{array}$ & 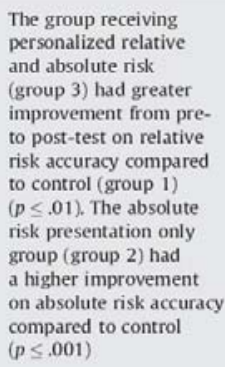 \\
\hline $\begin{array}{l}\text { Glazebrook et al. [28]: } \\
\text { UK; high quality }\end{array}$ & $\begin{array}{l}\text { (1) Interactive tailored } \\
\text { multimedia intervention; } \\
\text { (2) no intervention: on } \\
\text { skin cancer }\end{array}$ & $\begin{array}{l}\text { Risk factors for skin cancer: } \\
\text { - Skin characteristics } \\
\text { - Sunburn history } \\
\text { - Family history: HBM } \\
\text { \& Social Ecological Model }\end{array}$ & $\begin{array}{l}\text { Convenience sample of } \\
\text { surgeries at ten family } \\
\text { practices randomized } \\
\text { at practice level }\end{array}$ & $\begin{array}{l}808 \text { female: } \bar{x}(\mathrm{SD})= \\
38(15) \text { yr: family practice } \\
\text { patients with higher risk } \\
\text { skin characteristics }\end{array}$ & $\begin{array}{l}\text { 589: } 70 \%: 22 \%: \\
1,2,6 \text { and } 7\end{array}$ & $\begin{array}{l}\text { - Knowledge of } \\
\text { melanoma } \\
\text { - Perceived risk } \\
\text { - Mole checking }\end{array}$ & $\begin{array}{l}6 \text { mo post-intervention } \\
\text { higher increase in } \\
\text { knowledge (OR }=.51 \text { : } \\
\text { a } 30-.72, p<.001 \text { ) } \\
\text { and mole checking } \\
\text { (OR }=1.67 . \mathrm{Cl} 1.04-2.70 . \\
p=.035 \text { ) in intervention } \\
\text { group compared to } \\
\text { control }\end{array}$ \\
\hline $\begin{array}{l}\text { Jerant et al. [37]: USA: } \\
\text { low quality }\end{array}$ & $\begin{array}{l}\text { (1) Tailored interactive } \\
\text { multimedia computer } \\
\text { program: (2) non-tailored } \\
\text { interactive multimedia } \\
\text { computer program: to } \\
\text { encourage CRC screening }\end{array}$ & $\begin{array}{l}\text { - Patient preference } \\
\text { - Self-efficacy } \\
\text { - Barriers } \\
\text { - Readiness; TTM }\end{array}$ & $\begin{array}{l}\text { Recruited by tel prior to } \\
\text { visit. Subjects arrived } 60 \text { min } \\
\text { before scheduled appointment } \\
\text { to use the software in the } \\
\text { primary care office }\end{array}$ & $\begin{array}{l}\text { 63\% female; } \chi=60 \mathrm{yr} \text { : } \\
\text { non-CRC affected: } \\
\text { enrollees } 50 \text { or older }\end{array}$ & 49: 47x: NA; 1 & $\begin{array}{l}\text { - CRC screening } \\
\text { knowledge } \\
\text { - Self-efficacy } \\
\text { - Benefits } \\
\text { - Barriers } \\
\text { - Stage of readiness }\end{array}$ & $\begin{array}{l}\text { Immediately post-visit } \\
\text { tailored intervention } \\
\text { group had an increase } \\
\text { in CRC screening } \\
\text { self-efficacy }(p=0.049) \text {. } \\
\text { greater likelihood of } \\
\text { moving to a more } \\
\text { advanced stage of } \\
\text { readiness }(p-.034)\end{array}$ \\
\hline $\begin{array}{l}\text { Jibaja-Weiss et al. [38]: } \\
\text { USA; moderate } \\
\text { quality }\end{array}$ & $\begin{array}{l}\text { (1) Personalized tailored } \\
\text { letter (2) personalized } \\
\text { form letter with risk } \\
\text { factor information on } \\
\text { BC and cervical cancer }\end{array}$ & $\begin{array}{l}\text { Cancer risk factors: } \\
\text { - Age } \\
\text { - Positive FM } \\
\text { - Parity } \\
\text { - BMI } \\
\text { - Ethnicity: HBM }\end{array}$ & $\begin{array}{l}\text { Eligible women were identified } \\
\text { from medical records and } \\
\text { received a mailing }\end{array}$ & $\begin{array}{l}100 \% \text { female: } x(\mathrm{SD})= \\
39(13) \mathrm{yr} \text { non- } \mathrm{BC} / \mathrm{OC} \\
\text { affected: urban; low- } \\
\text { income minority }\end{array}$ & $\begin{array}{l}\text { 1574: 90\%; NA: } \\
1,3 \text { and } 4\end{array}$ & $\begin{array}{l}\text { - Scheduling } \\
\text { appointment for } \\
\text { cancer rcreening } \\
\text { - Receiving cancer } \\
\text { screening (papterst } \\
\text { and mammo): } \\
\text { based on registration }\end{array}$ & $\begin{array}{l}\text { Women in group } 1 \text { had } \\
\text { the lowest pap-test } \\
\text { and mammography } \\
\text { rate within 1 year. } \\
\text { compared to group } \\
2 \text { and control group } \\
(p<<.01 \text { ). Women in } \\
\text { group } 2 \text { had higher } \\
\text { screening ratest than } \\
\text { control }(p<<.001)\end{array}$ \\
\hline
\end{tabular}




\begin{tabular}{|c|c|c|c|c|c|c|c|}
\hline $\begin{array}{l}\text { Study: country: } \\
\text { quality }\end{array}$ & Intervention groups & $\begin{array}{l}\text { Tailoring characteristics: } \\
\text { theory-basea }\end{array}$ & Recruitment & $\begin{array}{l}\text { Participants (gender, age. } \\
\text { disease status, ethnicity, } \\
\text { health care setting)" }\end{array}$ & $\begin{array}{l}N^{b} \text {; response drop } \\
\text { out? fulfilled } \\
\text { quality criteriac }\end{array}$ & $\begin{array}{l}\text { Outcome } \\
\text { measures }\end{array}$ & $\begin{array}{l}\text { Significant effects for } \\
\text { all study } \\
\text { participants }(p<.05)\end{array}$ \\
\hline $\begin{array}{l}\text { Kreuter et al. [40]: } \\
\text { uSA: moderate } \\
\text { quality }\end{array}$ & $\begin{array}{l}\text { (1) } 6 \text { issues of a tailored } \\
\text { women's health magazine: } \\
\text { (2) no intervention; on } \\
\text { mammo }\end{array}$ & $\begin{array}{l}\text { - Knowledge } \\
\text { - Motivation } \\
\text { - Self-efficacy } \\
\text { - Spirituality } \\
\text { - Collectivism } \\
\text { - Racial pride } \\
\text { - Time orientation }\end{array}$ & $\begin{array}{l}\text { Women at urban public health } \\
\text { centres completed baseline } \\
\text { questionnaire in waiting area }\end{array}$ & $\begin{array}{l}1005 \text { female: } x=36 \mathrm{yr} ; \\
\text { low-income: African } \\
\text { American }\end{array}$ & $1227: 1.2$ and 7 & $\begin{array}{l}\text { - Self-reported } \\
\text { mammo use }\end{array}$ & $\begin{array}{l}17 \text { mo post-intervention } \\
\text { Intervention group was } \\
\text { more likely to report } \\
\text { a mammo than control } \\
\text { (OR - } 2.6, \text { Cl 1.1-6.1) }\end{array}$ \\
\hline $\begin{array}{l}\text { Kreuter and } \\
\text { Strecher [20|: } \\
\text { USA: low quality }\end{array}$ & $\begin{array}{l}\text { (1) Individualized risk } \\
\text { feedback and behavior } \\
\text { change feedback: (2) only } \\
\text { individualized risk feedback; } \\
\text { (3) no feedback; from health } \\
\text { risk appraisal }\end{array}$ & $\begin{array}{l}\text { - Demographics } \\
\text { - Risk factors } \\
\text { - Barriers to and benefits } \\
\text { from changing risky } \\
\text { behaviors } \\
\text { - Perceived risk of hart } \\
\text { attack, stroke, cancer } \\
\text { and motor vehicle crash: } \\
\text { TTM \& HBM }\end{array}$ & $\begin{array}{l}\text { Eligible participants were } \\
\text { approached by research } \\
\text { assistants in the waiting } \\
\text { room of } 8 \text { GPs }\end{array}$ & $65 \%$ female: $\bar{x}=40 \mathrm{yr}$ & $\begin{array}{l}\text { 1317: 80x: 14\%: } \\
1 \text { and } 7\end{array}$ & $\begin{array}{l}\text { - Mammo use } \\
\text { - Pap smear use }\end{array}$ & $\begin{array}{l}6 \text { mo patients in group } \\
1 \text { were } 18 \text { more likely } \\
\text { to change at least one } \\
\text { risk behavior } p<.05 \text {. } \\
\text { no effect on pap or } \\
\text { mammo }\end{array}$ \\
\hline $\begin{array}{l}\text { Kreuter and } \\
\text { Strecher [19]: } \\
\text { USA; low quality }\end{array}$ & $\begin{array}{l}\text { (1) Individualized risk } \\
\text { feedback and behavior } \\
\text { change feedback: (2) only } \\
\text { individualized risk feedback; } \\
\text { (3) no feedback: from health } \\
\text { risk appraisal }\end{array}$ & $\begin{array}{l}\text { - Demographics } \\
\text { - Risk factors } \\
\text { - Barriers to and benefits } \\
\text { from changing risky } \\
\text { behaviors } \\
\text { - Perceived risk of hart } \\
\text { attack, stroke, cancer } \\
\text { and motor vehicle crash }\end{array}$ & $\begin{array}{l}\text { Eligible participants were } \\
\text { approached in the waiting } \\
\text { room of } 8 \mathrm{GPs}\end{array}$ & 65x female; $40 \mathrm{yr}$ & $\begin{array}{l}\text { 1317; } 80 x ; 14 \% ; \\
1 \text { and } 7\end{array}$ & $\begin{array}{l}\text { - Cancer risk } \\
\text { perception }\end{array}$ & $\begin{array}{l}6 \text { mo individualized } \\
\text { risk feedback reduced } \\
\text { perceived cancer risk } \\
\text { among over estimators } \\
\text { (OR }-1.36, p<.05)\end{array}$ \\
\hline $\begin{array}{l}\text { Lipkus et al. |53|; } \\
\text { USA: low quality }\end{array}$ & $\begin{array}{l}\text { (1) General and tailored info; } \\
\text { (2) 1 plus relative risk } \\
\text { estimation: (3) general } \\
\text { info on CRC risk }\end{array}$ & $\begin{array}{l}\text { CRC lifestyle risk factors: } \\
\text { - Diet } \\
\text { - Exercise } \\
\text { - Smoking }\end{array}$ & $\begin{array}{l}\text { Advertisement in local } \\
\text { newspaper }\end{array}$ & 63\% female; $\bar{x}=56 \mathrm{yr}$ & $160 ; 88 x ; 1$ & $\begin{array}{l}\text { - Ambivalence } \\
\text { towards FOBT } \\
\text { screening } \\
\text { - Intentions towards } \\
\text { FOBI screening } \\
\text { - FOBT screening rate }\end{array}$ & $\begin{array}{l}\text { Immediately post- } \\
\text { intervention group } \\
2 \text { had lower } \\
\text { ambivalence }(F-10.4) \\
\text { and higher score on } \\
\text { intentions ( } F=132.7) \\
\text { than control (group } 3) \\
(p<.05)\end{array}$ \\
\hline $\begin{array}{l}\text { Lipkus et al. |411: } \\
\text { USA: low quality }\end{array}$ & $\begin{array}{l}\text { (1) Tailored print: } \\
\text { (2) tailored tel counseling: } \\
\text { (3) UC to promote mammo }\end{array}$ & $\begin{array}{l}\text { - Barriers to mammo } \\
\text { - Stage of mammo } \\
\text { adoption: TTM }\end{array}$ & $\begin{array}{l}\text { Study invitation was } \\
\text { mailed to patients } \\
\text { registered at an HMO }\end{array}$ & $\begin{array}{l}100 \% \text { female: } x-60 \text { yr: } \\
\text { not } B C \text { patient or } \\
\text { double mastectomy }\end{array}$ & $\begin{array}{l}\text { 1099: 44\%: } 9 \%: \\
1 \text { and } 7\end{array}$ & $\begin{array}{l}\text { Self-reported } \\
\text { adherence to } \\
\text { mammo screening }\end{array}$ & $\begin{array}{l}2 \text { yr print vs. uc (OR - } \\
1.38: C 1.99-1.92 . \\
p=.056)\end{array}$ \\
\hline
\end{tabular}




\begin{tabular}{|c|c|c|c|c|c|c|c|}
\hline $\begin{array}{l}\text { Marcus et al. [54]: } \\
\text { USA; low quality }\end{array}$ & $\begin{array}{l}\text { (1) } 4 \text { re-tailored B (booklets); } \\
\text { (2) } 4 \text { tailored B; ( } 3 \text { ) } 1 \\
\text { tailored B: (4) i standard } \\
\text { booklet to promote FoBT }\end{array}$ & $\begin{array}{l}\text { - Knowledge of age } \\
\text { eligibility and interval } \\
\text { of FBT } \\
\text { - CRC risk factors } \\
\text { - Barriers for FoBT } \\
\text { - Stage of change; } \\
\text { TTM \& HBM }\end{array}$ & $\begin{array}{l}\text { Baseline interview } \\
\text { at the end of the usual } \\
\text { call to the cIs }\end{array}$ & $\begin{array}{l}838 \text { female: } 50850-59 \mathrm{yr} \text { : } \\
\text { no cancer treatment; callers } \\
\text { to Cancer Information } \\
\text { Centre eligible for FoBT }\end{array}$ & $\begin{array}{l}\text { 4014: 67\%: 45\%: } \\
1 \text { and } 7\end{array}$ & $\begin{array}{l}\text { - Self-reported } \\
\text { CRC screening rate }\end{array}$ & $\begin{array}{l}14 \text { mo difference } \\
\text { between the } \\
\text { intervention group } \\
\text { receiving } 4 \text { tailored } \\
\text { booklets and the } \\
\text { control group } \\
\text { receiving standard } \\
\text { information, respectively } \\
51 \text { vs. } 422 \text { CRC } \\
\text { screening rate }(p<.03)\end{array}$ \\
\hline $\begin{array}{l}\text { McBride et al. [42]: } \\
\text { uSA; moderate } \\
\text { quality }\end{array}$ & $\begin{array}{l}\text { (1) Biomarker feedback on } \\
\text { susceptibility for lung cancer } \\
\text { in tailored test result booklet } \\
\text { with self-help manual and } \\
\text { nicotine patches: (2) self-help } \\
\text { manual and nicotine patches }\end{array}$ & $\begin{array}{l}\text { - Test results } \\
\text { - Gender } \\
\text { - Age } \\
\text { - Number of yr smoked }\end{array}$ & $\begin{array}{l}\text { The study screening } \\
\text { survey was administered } \\
\text { by the smoking specialist } \\
\text { immediately after the } \\
\text { clinic visit }\end{array}$ & $\begin{array}{l}608 \text { female: } x=44(12) \text { yr: } \\
\text { African American: } \\
\text { low-income }\end{array}$ & $\begin{array}{l}\text { 557: 87\%: } 26 \%: \\
1,6 \text { and } 7\end{array}$ & $\begin{array}{l}\text { - Self-reported } \\
\text { smoking cessation } \\
\text { - Risk perception } \\
\text { - Lung cancer worry } \\
\text { - Depression }\end{array}$ & None \\
\hline $\begin{array}{l}\text { Mocaul et al. 1431: } \\
\text { USA: low quality }\end{array}$ & $\begin{array}{l}\text { (1) Reminder and tailored } \\
\text { letter: (2) remininder and } \\
\text { general risk info: } \\
\text { (3) reminder (4) no } \\
\text { reminder; on mammo }\end{array}$ & $\begin{array}{l}\text { Barriers: } \\
\text { - No time } \\
\text { - Little information } \\
\text { - High age } \\
\text { - Low risk perception } \\
\text { - Costs } \\
\text { - No referral } \\
\text { - Pain }\end{array}$ & Medicare participants & $100 \%$ female & 3887: 21\%: NA: 1 & - Mammo screening & None \\
\hline $\begin{array}{l}\text { Prochaska et al. [45]; } \\
\text { USA: high quality }\end{array}$ & $\begin{array}{l}\text { (1) Stage-based expert system } \\
\text { to reduce smoking. improve } \\
\text { diet, decrease sun exposure } \\
\text { and prevent relapse from } \\
\text { regular mammo; (2) no } \\
\text { intervention }\end{array}$ & $\begin{array}{l}\text { - Risk behavior } \\
\text { - Stage of change } \\
\text { - Readiness to change } \\
\text { - Pros and cons } \\
\text { - Change processes: TTM }\end{array}$ & $\begin{array}{l}\text { Patients from } 79 \text { GPS, } \\
\text { identified from the registration } \\
\text { of a health insurance } \\
\text { organization, were } \\
\text { contacted by phone }\end{array}$ & $\begin{array}{l}70 \% \text { female: } X(S D)= \\
45(13) \text { yr: GP patients } \\
\text { being at risk for at least } \\
\text { one of the four health } \\
\text { risk behaviors }\end{array}$ & $\begin{array}{l}\text { 5407: 69\%: 25\%: } \\
1.2 .5 \text { and } 7\end{array}$ & $\begin{array}{l}\text { - Stage of change } \\
\text { progression } \\
\text { - Belavior outcomes } \\
\text { for mammm screening }\end{array}$ & $\begin{array}{l}24 \text { mo post-intervention } \\
\text { none on manmo }\end{array}$ \\
\hline $\begin{array}{l}\text { Rakowski et al. [46]; } \\
\text { USA: moderate } \\
\text { quality }\end{array}$ & $\begin{array}{l}\text { (1) Stage-matched; } \\
\text { (2) standard: (3) no materials: } \\
\text { on mammo with a provider } \\
\text { directed component }\end{array}$ & $\begin{array}{l}\text { - Stage of mammo adoption } \\
\text { - Decisional balance; } \mathrm{TTM}\end{array}$ & $\begin{array}{l}\text { Women identified by HMO } \\
\text { registration at } 5 \text { sites } \\
\text { were randomly selected } \\
\text { and send a letter }\end{array}$ & $50 \%$ female & $\begin{array}{l}1397 ; 74 \% ; \mathrm{NA} ; \\
1.2 \text { and } 7\end{array}$ & $\begin{array}{l}\text { - Record based } \\
\text { mammo screening }\end{array}$ & $\begin{array}{l}19-21 \text { mo post- } \\
\text { intervention stage- } \\
\text { matched vs. no } \\
\text { material }(O R=1.43 \text {. } \\
C=1.10-1.86, p<.05)\end{array}$ \\
\hline
\end{tabular}




\begin{tabular}{|c|c|c|c|c|c|c|c|}
\hline $\begin{array}{l}\text { Study: country: } \\
\text { quality }\end{array}$ & Intervention groups & $\begin{array}{l}\text { Tailoring characteristics: } \\
\text { theory-base }\end{array}$ & Recruitment & $\begin{array}{l}\text { Participants (gender, age. } \\
\text { disease status, ethnicity. } \\
\text { health care setting)" }\end{array}$ & $\begin{array}{l}N^{N} \text { : response drop } \\
\text { out"; fulfilled } \\
\text { quality criteriac }\end{array}$ & $\begin{array}{l}\text { Outcome } \\
\text { measures }\end{array}$ & $\begin{array}{l}\text { Significant effects for } \\
\text { all study } \\
\text { participants }(p<.05)\end{array}$ \\
\hline $\begin{array}{l}\text { Rimer et al. [29]: } \\
\text { USA: low quality }\end{array}$ & $\begin{array}{l}\text { (1) Tailored print materials; } \\
\text { (2) tailored print materials } \\
\text { plus tailored tel counseling: } \\
\text { (3) UC (standard reminder } \\
\text { postcard): for mammo } \\
\text { decision-making }\end{array}$ & $\begin{array}{l}\text { Mammo readiness, intentions, } \\
\text { mammmo history, benefits } \\
\text { and limitations, mammor risk } \\
\text { perceptions, age. BC risk } \\
\text { factors, perceived risks. } \\
\text { barriers, pros and cons. } \\
\text { screening recommendations, } \\
\text { ambivilence, sufficiency of } \\
\text { info for informed decios: } \\
\text { TTM \& PAPM }\end{array}$ & $\begin{array}{l}\text { Tel interviews with randomly } \\
\text { selected members from } \\
\text { Blue Cross Clue Shield of } \\
\text { North Carolina }\end{array}$ & $\begin{array}{l}100 \% \text { female: } 50 \% 40- \\
44 \mathrm{yr}: 50 \% 50-54 \mathrm{yr}\end{array}$ & $\begin{array}{l}\text { 1287; 76\%; } 2 \% ; \\
1 \text { and } 7\end{array}$ & $\begin{array}{l}\text { - Knowledge of } \\
\text { BC and mammo } \\
\text { - Accuracy of BC } \\
\text { risk perceptions } \\
\text { - Use of mammo } \\
12 \text { and } 24 \mathrm{mo} \text { after } \\
\text { intervention } \\
\text { (self-reported) }\end{array}$ & $\begin{array}{l}24 \text { mo follow-up tailored } \\
\text { print had compared to UC, } \\
\text { effects on knowledge and } \\
\text { accuracy of risk perception. } \\
\text { Tailored print and tel } \\
\text { counseling combined had } \\
\text { positive effect on all } \\
\text { three outcome measures. } \\
\text { These group } 2 \text { respondents } \\
\text { were more likely to have } \\
\text { had mammo compared to } \\
\text { other groups (OR }=1.4 \text {, } \\
p=.03 \text { ) }\end{array}$ \\
\hline $\begin{array}{l}\text { Rimer et al. [30]; } \\
\text { USA; low quality }\end{array}$ & $\begin{array}{l}\text { (1) Tailored print materials; } \\
\text { (2) 1 plus tailored tel } \\
\text { counseling: (3) UC (standard } \\
\text { reminder letter) for mammo } \\
\text { decision }\end{array}$ & see Rimer 2002 & $\begin{array}{l}\text { Interviews with randomly } \\
\text { selected members from } \\
\text { Blue Cross Clue Shield }\end{array}$ & $\begin{array}{l}\text { 100\% female; in their } \\
40 s / 50 \mathrm{~s}\end{array}$ & $\begin{array}{l}\text { 1287; 76\%; 88; } \\
1 \text { and } 7\end{array}$ & $\begin{array}{l}\text { - Knowledge of } \\
\text { BC and manmmo } \\
- \text { Accuracy of BC } \\
\text { risk perceptions } \\
\text { - Attitudes toward } \\
\text { mammo } \\
\text { - Satisfaction with } \\
\text { decisions } \\
\text { - Mammo use }\end{array}$ & $\begin{array}{l}12 \text { mo post-intervention } \\
\text { the combination of } \\
\text { tailored print and tel } \\
\text { counseling had effects } \\
\text { on all outcome measures. } \\
\text { more knowledge ( } p<.007)\end{array}$ \\
\hline $\begin{array}{l}\text { Rimer et al. |48]; } \\
\text { USA; low quality }\end{array}$ & $\begin{array}{l}\text { (1) Provider prompting; } \\
\text { (2) } 1 \text { and tailored print } \\
\text { materials: (3) } 2 \text { with tailored } \\
\text { tel counseling }\end{array}$ & $\begin{array}{l}\text { Screening history, test } \\
\text { results, mammo stage } \\
\text { and pap-test, barriers. } \\
\text { pros and cons, previous } \\
\text { hysterectomy, race, age: } \\
\text { TTM }\end{array}$ & $\begin{array}{l}\text { Women attending a } \\
\text { community health centre }\end{array}$ & $\begin{array}{l}1000 \text { female: } \bar{X}(\mathrm{SD})= \\
51(18) \text { yr: low-income } \\
\text { black }\end{array}$ & 1318; $71 \% ; 28 \%$ & $\begin{array}{l}\text { - Mammo use } \\
\text { - Pap-test use } \\
\text { - Overall cancer } \\
\text { screening compliance }\end{array}$ & $\begin{array}{l}16 \text { mo group } 3 \text { had more } \\
\text { pap-test compliance } \\
(p=.05) \text { and overall } \\
\text { cancer screening } \\
\text { compliance }(p=.006)\end{array}$ \\
\hline $\begin{array}{l}\text { Saywell et al. [49]; } \\
\text { USA; low quality }\end{array}$ & $\begin{array}{l}\text { (1) Tailored tel: (2) tailored } \\
\text { mail: ( } 3 \text { ) tailored tel and } \\
\text { tailored mail to promote } \\
\text { mammo; (4) UC (no } \\
\text { intervention) }\end{array}$ & $\begin{array}{l}\text { Perceived BC susceptibility. } \\
\text { perceived risk, benefits } \\
\text { and barriers, self-efficacy. } \\
\text { family history, stage of } \\
\text { mammo adoption, age: HBM }\end{array}$ & $\begin{array}{l}\text { Patients at a general medicine } \\
\text { clinic or enrolled with one } \\
\text { of two managed care } \\
\text { organizations }\end{array}$ & $\begin{array}{l}100 \% \text { female: } X-66 \mathrm{yr} \text { : } \\
\geq 51 \text { yr; no } B C \text { history; } \\
\text { no mammo in } 15 \mathrm{mo}\end{array}$ & 1044: 75\%: 2x: 1 & $\begin{array}{l}\text { - Self-reported } \\
\text { mammo use }\end{array}$ & $\begin{array}{l}2 \text { mo post-intervention } \\
\text { all } 3 \text { interventions } \\
\text { increased mammo } \\
\text { compared to UC. (Group } \\
2 \text { compared to UC: OR = } \\
1.6, p=.009 \text { ). }\end{array}$ \\
\hline $\begin{array}{l}\text { Skinner et al. [26]: } \\
\text { USA; moderate quality }\end{array}$ & $\begin{array}{l}\text { (1) Tailored tel: (2) tailored } \\
\text { mail; ( } 3 \text { ) } 1 \text { and } 2 ;(4) \text { UC } \\
\text { (no intervention) to } \\
\text { promote mammo }\end{array}$ & $\begin{array}{l}\text { Perceived susceptibility, } \\
\text { benefits, barriers, } \\
\text { self-efficacy and stage } \\
\text { of mammo adoption; } \\
\text { TTM \& HBM }\end{array}$ & $\begin{array}{l}\text { Visited university-affiliated } \\
\text { clinic in past } 12 \text { mo or } \\
\text { enrolled with one of } \\
\text { two HMOs }\end{array}$ & $\begin{array}{l}1008 \text { female; } \bar{x}=65 \mathrm{yr} \text {; } \\
251 \text { yr; no BC history } \\
\text { no mammo last } 15 \text { mo }\end{array}$ & $657 ; 1,6$ and 7 & $\begin{array}{l}\text { - Having a second } \\
\text { mammo at } 15 \text { mo }\end{array}$ & $\begin{array}{l}\begin{array}{l}\text { Only results for } \\
\text { effectiveness of booster } \\
\text { dese reported: }\end{array} \\
6 \text { mo post-intervention } \\
\text { booster vs. none (OR- } \\
1.73 \text {, } p=046 \text { ) } \\
\text { NS at } 15 \text { mo post- } \\
\text { intervention }\end{array}$ \\
\hline
\end{tabular}




\begin{tabular}{|c|c|c|c|c|c|c|c|}
\hline $\begin{array}{l}\text { Skinner et al. [61]: } \\
\text { USA; low quality }\end{array}$ & $\begin{array}{l}\text { (1) Tailored print materials; } \\
\text { (2) non-tailored print } \\
\text { materials; in BC and } \mathrm{OC} \\
\text { genetic counseling }\end{array}$ & $\begin{array}{l}\text { Sociodemographic/medical } \\
\text { characteristics, pros and } \\
\text { cons of testing. worry. } \\
\text { ifformation preferences, } \\
\text { knowledge, probability } \\
\text { of having a mutation }\end{array}$ & & $\begin{array}{l}100 \% \text { female; } \bar{x}- \\
49(10) \text { yr; } 89 \% \mathrm{BC} \\
\text { affected counselees in } \\
\text { genertic counseling } \\
\text { for } \mathrm{BC} \text { and } \mathrm{OC}\end{array}$ & $325(70 \%): 1$ and 7 & $\begin{array}{l}\text { - Knowledge of BC } \\
\text { and heredity } \\
\text { - Accuracy perceived } \\
\text { risk of being a } \\
\text { mutation carrier } \\
\text { - Worry about } \\
\text { having a gene } \\
\text { alteration }\end{array}$ & $\begin{array}{l}2 \text { wk follow-up } \\
\text { intervention group } \\
\text { exhibited greater } \\
\text { improvement in } \\
\text { knowledge ( } p<.0001) \\
\text { and less over-estimation } \\
\text { of risk of eeing a } \\
\text { mutation carrier (Kappa } \\
\text {.33: } 22 \text {-.-44: between } \\
\text { group difference } p<.0001 \text { ) }\end{array}$ \\
\hline $\begin{array}{l}\text { Skinner et al. [50|: } \\
\text { USA: low quality }\end{array}$ & $\begin{array}{l}\text { (1) Tailored vs. (2) standard } \\
\text { printed recommendations } \\
\text { to promote mammo screening }\end{array}$ & $\begin{array}{l}\text { - Beliefs } \\
\text { - Barriers to mammo } \\
\text { - - risk factors } \\
\text { - Screening status; TTM }\end{array}$ & $\begin{array}{l}\text { Women who had visited } \\
\text { family practice groups } \\
\text { within the previous } 2 \text { yr }\end{array}$ & $\begin{array}{l}1008 \text { female: } 40- \\
65 \text { yr; non-BC affected }\end{array}$ & $435: 57 \%: 1$ and 7 & $\begin{array}{l}\text { - Testing intention } \\
- \text { Reacll } \\
- \text { Readership } \\
\text { - Mammo stage } \\
\text { movement } \\
\text { - Barriers }\end{array}$ & $\begin{array}{l}\text { Tailored letter recipients } \\
\text { were more likely to } \\
\text { remember }(p<.05) \\
\text { and to have read more } \\
\text { of their letters }(p<.01) \\
\text { than standardized version } \\
\text { recipients }\end{array}$ \\
\hline $\begin{array}{l}\text { Weinstein et al. [51]: } \\
\text { USA; low quality }\end{array}$ & $\begin{array}{l}\text { (1) Computer program } \\
\text { providing colon cancer } \\
\text { riskinfinformation: }(2) 1 \text { with } \\
\text { personalized absolute risk } \\
\text { estimation: (3) 2 with } \\
\text { personalized relative risk } \\
\text { estimation }\end{array}$ & $\begin{array}{l}\text { Risk factors for colon cancer: } \\
\text { - Family history } \\
\text { - Weight } \\
\text { - Diet } \\
\text { - Physical activity } \\
\text { - Colorectal cancer screening }\end{array}$ & $\begin{array}{l}\text { Patients with scheduled } \\
\text { routine health care er } \\
\text { non-urgent care visis at } \\
2 \text { primary care practices } \\
\text { between } 40 \text { and } 70 \text { yr of } \\
\text { age received a letter } \\
\text { followed by a tel call }\end{array}$ & $\begin{array}{l}\text { 55\% female: } x=55 \text { yr: } \\
\text { non-affected; primary } \\
\text { care patients }\end{array}$ & 353: 25\%: NA: 1 & $\begin{array}{l}\text { - Accuracy of } \\
\text { perceived risk }\end{array}$ & $\begin{array}{l}\text { Accuracy of mean risk } \\
\text { estimates improved. } \\
\text { Relative risk was } \\
\text { perceived most } \\
\text { accurate by group } \\
3(F=2.3, p<.001) \\
\text { and absolute risk by } \\
\text { group } 2 \text { and } 3 \text { ( } F= \\
\text { 2.3. } p<.0001) \text {. About } \\
\text { half of participants did } \\
\text { not accept the personalized } \\
\text { feedback as correct }\end{array}$ \\
\hline
\end{tabular}


Table 2
Characteristics and effects of randomized designs comparing multicomponent interventions which include tailored information vs. other interventions or usual care.

\begin{tabular}{|c|c|c|c|c|c|c|c|c|}
\hline Study: country & Intervention groups & $\begin{array}{l}\text { Tailoring characteristics: } \\
\text { theory basea }\end{array}$ & Recruitment & $\begin{array}{l}\text { Participants (gender. } \\
\text { age, disease status, } \\
\text { ethinicity, healthcare } \\
\text { setting) }\end{array}$ & Design & $\begin{array}{l}N^{b} \text { : response } \\
\text { drop out }^{a}\end{array}$ & Outcome measures & $\begin{array}{l}\text { Significant effects } \\
\text { for all study } \\
\text { participants }(p<.05)\end{array}$ \\
\hline $\begin{array}{l}\text { Campbell et al. } \\
\text { [57]: USA }\end{array}$ & $\begin{array}{l}\text { (1) } 4 \text { tailored } \\
\text { newsletters, targeted } \\
\text { videotapes: (2) lay } \\
\text { health advisor } \\
\text { intervention: } \\
\text { no intervention combined } 2:(4) \\
\text { with at least } 3 \text { church } \\
\text { activities to promote CRC } \\
\text { prevention behaviors }\end{array}$ & $\begin{array}{l}\text { - CRC screening } \\
\text { - CRC risk factors } \\
\text { - Stages of change } \\
\text { - Social support } \\
\text { - Barriers to change } \\
\text { - Beliefs } \\
\text { - Demographics (age, gender) } \\
\text { - Church; TMM \& HBM \& } \\
\text { Social Cognitive Theory }\end{array}$ & $\begin{array}{l}\text { Churches provided } \\
\text { lists of members } \\
\geq 18 \text { yr. attending } \\
\text { church at least once } \\
\text { a mo. Recruitment } \\
\text { by mail package and } \\
\text { tel interviews. } \\
\text { A health fair was the } \\
\text { kick of of the project }\end{array}$ & $\begin{array}{l}74 \% \text { female; } \bar{x}-51 \mathrm{yr} \text {; } \\
>50 \mathrm{yr} \text { : CRC screening } \\
\text { relevant: active church } \\
\text { members }\end{array}$ & $\begin{array}{l}\text { RCT } \\
\text { randomized } \\
\text { on church } \\
\text { level }\end{array}$ & 287: 58\%; 28\% & $\begin{array}{l}\text { - Self-reported CRC } \\
\text { screening rate (FOBT) }\end{array}$ & $\begin{array}{l}12 \text { mo group } 1 \\
\text { demonstrated greatest } \\
\text { increase, } 37 \% \text { screened } \\
\text { vs. } 33 \% \text { group } 2 . \\
12 \text { mo post- } \\
\text { intervention no } p< \\
.05 \text { effects }\end{array}$ \\
\hline $\begin{array}{l}\text { Campbell et al. } \\
\text { [55]: USA }\end{array}$ & $\begin{array}{l}\text { (1) } 2 \text { tailored magazines } \\
\text { with a natural helpers } \\
\text { intervention to promote } \\
\text { mammo and pap-test } \\
\text { use: (2) no intervention }\end{array}$ & $\begin{array}{l}\text { - Workplace } \\
\text { - Age } \\
\text { - Shift } \\
\text { - Health concerns } \\
\text { - Health behaviors- Smoking } \\
\text { - Cancer screening } \\
\text { - Change priority: TTM \& } \\
\text { Social Cognitive Theory }\end{array}$ & $\begin{array}{l}19 \text { worksites were } \\
\text { eligible in } 9 \text { rural } \\
\text { counties and } 10 \\
\text { were recruited }\end{array}$ & $\begin{array}{l}100 \% \text { female; } 53 \% \text { - } 18- \\
40 \text { yr: blue collar workers } \\
\text { (textile or light } \\
\text { manufacturing industry) }\end{array}$ & $\begin{array}{l}\text { RCT } \\
\text { randomized } \\
\text { on work-place } \\
\text { level }\end{array}$ & $538 ; 73 \% ; 1 \%$ & $\begin{array}{l}\text { - Self-reported } \\
\text { screening rate } \\
\text { for pap-test and } \\
\text { mammo }\end{array}$ & None \\
\hline $\begin{array}{l}\text { Emmons et al. } \\
\text { [58]: USA }\end{array}$ & $\begin{array}{l}\text { (1) Tel peer counseling. } \\
\text { tailored and targeted } \\
\text { materials, nicotine } \\
\text { replacement therapy: (2) } \\
\text { self-help for smoking } \\
\text { cessation }\end{array}$ & $\begin{array}{l}\text { - Cancer type } \\
\text { - Treatment } \\
\text { - Risk perception } \\
\text { - Self-efficacy } \\
\text { - Motivation }\end{array}$ & $\begin{array}{l}\text { Respondents recruited } \\
\text { from the Childhood } \\
\text { Cancer Survivor Study }\end{array}$ & $\begin{array}{l}47 \% \text { female: } x(\mathrm{SD})= \\
31 \text { (7) } \mathrm{yr}\end{array}$ & RCT & $796: 85 \%$ & - Risk perception & None \\
\hline $\begin{array}{l}\text { Geller et al. } \\
\text { [60]; USA }\end{array}$ & $\begin{array}{l}\text { (1) Goal-setting tel session. } \\
3 \text { sets of tailored materials } \\
\text { and } 3 \text { tailiored tel counseling } \\
\text { sessions. free screening: } \\
\text { (2) UC (dermatologists } \\
\text { suggests patient to inform } \\
\text { family on risk and screening): } \\
\text { to promote skin cancer } \\
\text { preventive behavior and } \\
\text { screening }\end{array}$ & $\begin{array}{l}\text { Level of participation in } \\
\text { skin self-examination, } \\
\text { physician screening and } \\
\text { sun protection, self-efficacy, } \\
\text { knowledge and attitudes. } \\
\text { barriers to change, risk } \\
\text { perceptions: TMM \& HBM \& } \\
\text { Social Cognitive Theory \& } \\
\text { PAPM \& Theory of planned } \\
\text { behavior }\end{array}$ & $\begin{array}{l}\text { Dermatologist } \\
\text { approached recently } \\
\text { diagnosed melanoma } \\
\text { patients to provide } \\
\text { names and tel numbers } \\
\text { of siblings }\end{array}$ & $\begin{array}{l}\text { 548 female: age range - } \\
18-50 \text { yr: siblings of } \\
\text { recently-diagnosed } \\
\text { melanoma patients }\end{array}$ & RCT & 494: 74\%: $36 \%$ & $\begin{array}{l}\text { - Skin cancer screening } \\
\text { - Skin self-examination }\end{array}$ & $\begin{array}{l}12 \text { mo post- } \\
\text { intervention siblings } \\
\text { in the intervention } \\
\text { group were more } \\
\text { likely to examine } \\
\text { all the moles than } \\
\text { control }(\mathrm{OR}-1.76 \text {; } \\
\text { a } 1.06-2.91)\end{array}$ \\
\hline $\begin{array}{l}\text { Jibaja et al. } \\
\text { |39|: USA }\end{array}$ & $\begin{array}{l}\text { (1) Interactive soap opera } \\
\text { as tailored computer-based } \\
\text { educational program: (2) } \\
\text { presentation by health } \\
\text { eductator plus receiving } \\
\text { material on BSE for BC } \\
\text { detection }\end{array}$ & $\begin{array}{l}\text { - Stage of change in BC } \\
\text { screening } \\
\text { - Age; TTM }\end{array}$ & $\begin{array}{l}\text { Eligible women identified } \\
\text { as they waited for health } \\
\text { services at an community } \\
\text { health clinic }\end{array}$ & $\begin{array}{l}100 \% \text { female: } 49 \% 18- \\
40 \mathrm{yr}: 51 \% 41-65 \mathrm{yr} \text { - } \\
\text { convenience sample } \\
\text { of Hispanic patients }\end{array}$ & RCT & 178; 128; NA & $\begin{array}{l}\text { - BC knowledge } \\
\text { - BC beliefs }\end{array}$ & $\begin{array}{l}\text { More increase in } \\
\text { knowledge and } \\
\text { beliefs in intervention } \\
\text { group than in the } \\
\text { comparison group } \\
(p<.05)\end{array}$ \\
\hline $\begin{array}{l}\text { Lipkus et al. } \\
\text { [56]; USA }\end{array}$ & $\begin{array}{l}\text { (1) Tailored risk factor } \\
\text { information in pritnt and } \\
\text { in tel counseling: (2) } \\
\text { non-tailored information } \\
\text { in print on CRC risk }\end{array}$ & $\begin{array}{l}\text { Lifestyle and occupational } \\
\text { risk factors: } \\
\text {-Diet } \\
\text { - Exercise } \\
\text { - Smoking } \\
\text { - FoB screening } \\
\text { - Exposure to wood dust, } \\
\text { solvents. achestos }\end{array}$ & & $\begin{array}{l}\text { Carpenters; aged 50-75: } \\
\text { no colon cancer history: } \\
\text { no current cancer } \\
\text { treatment; no FoBt last } \\
15 \text { mo }\end{array}$ & RCT & $860 ; \mathrm{NA} ; 29 \%$ & $\begin{array}{l}\text { - Knowledge of CRC risk } \\
\text { factors } \\
\text { - Perceived CRC risk } \\
\text { - Negative emotions (i.e. } \\
\text { worry) }\end{array}$ & None \\
\hline
\end{tabular}

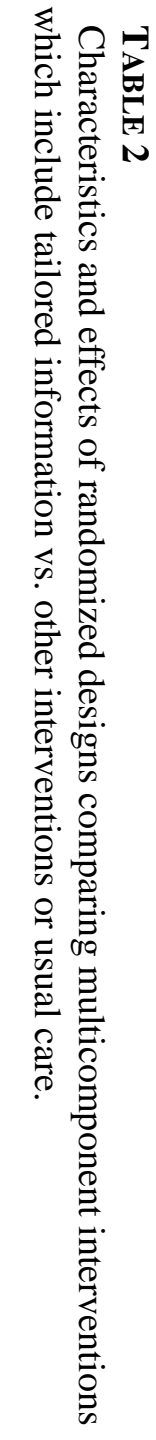




\begin{tabular}{|c|c|c|c|c|c|c|c|c|}
\hline $\begin{array}{l}\text { Marcus et al. } \\
\text { [25]: USA }\end{array}$ & $\begin{array}{l}\text { (1) Personalized follow-up } \\
\text { letter and pamphlet; } \\
\text { (2) transportation incentives; } \\
\text { (3) educational slide tape } \\
\text { program; ( } 4 \text { ) combinations } \\
\text { of 1-3 to promote pap-test } \\
\text { adherence }\end{array}$ & $\begin{array}{l}\text { - Pap smear results } \\
\text { - Further tests } \\
\text { - Urgency of follow-up }\end{array}$ & $\begin{array}{l}\text { All women with abnormal } \\
\text { pap-test results were } \\
\text { automatically enrolled }\end{array}$ & $\begin{array}{l}100 \% \text { female; age } 65 \% \\
\leq 29 \text { yr with abnormal } \\
\text { pap smear }\end{array}$ & RCT & 2044; NA; $29 \%$ & $\begin{array}{l}\text { - Return rate for pap } \\
\text { smear based on } \\
\text { medical record } \\
\text { registration }\end{array}$ & $\begin{array}{l}4 \text { mo post- } \\
\text { intervention effect of } \\
\text { (1) with a slide show in } \\
\text { waiting room (OR - } \\
2.3 ; \text { a } 1.21-4.34 \text { ). } \\
\text { Effect of transportation } \\
\text { incentives (OR 1.48: } \\
\text { a } 1.06-2.06 \text { ) }\end{array}$ \\
\hline $\begin{array}{l}\text { Myers et al. } \\
\text { |441) USA }\end{array}$ & $\begin{array}{l}\text { (1) Tailored print materials, } \\
\text { tailored tel contacts, standard } \\
\text { letter and reminder; (2) } \\
\text { standard letter and reminder } \\
\text { to increase adherence to } \\
\text { PC detection }\end{array}$ & $\begin{array}{l}\text {-Name } \\
\text { Risk factors: } \\
\text { - Age } \\
\text { - Race } \\
\text { - PC family history } \\
\text { - Presence of } \\
\text { PC symptoms }\end{array}$ & $\begin{array}{l}\text { Men identified from } \\
\text { patient files from a } \\
\text { university health centre } \\
\text { were send an advance } \\
\text { letter indicating a tel } \\
\text { survey }\end{array}$ & $\begin{array}{l}\text { 0o female; Age 40-70 yr; } \\
\text { African Americans: not } \\
\text { PC affected }\end{array}$ & RCT & 413 75\%; NA & $\begin{array}{l}\text { - Having an early } \\
\text { detection } \\
\text { exam }\end{array}$ & $\begin{array}{l}\text { Higher early detection } \\
\text { adherence in enhanced } \\
\text { intervention group } \\
\text { (51z vs. 29: OR - } \\
2.6: \text { ( 1 1.7-3.9) }\end{array}$ \\
\hline $\begin{array}{l}\text { Rakowski et al. } \\
\text { [47]; USA }\end{array}$ & $\begin{array}{l}\text { (1) Tailored stepped } \\
\text { interventions consisting } \\
\text { of a tailored letter, tip } \\
\text { sheets and a personal } \\
\text { counseling tel call: (2) } \\
\text { non-tailored reminder } \\
\text { letter on mammo }\end{array}$ & $\begin{array}{l}\text { Letter in the tailored stepped } \\
\text { intervention was stallored on: } \\
\text { barriers to mammo, knowledge } \\
\text { of recommended screening } \\
\text { interval. screening intention. } \\
\text { education, income, ethnicity. } \\
\text { number of persons in household }\end{array}$ & $\begin{array}{l}\text { Women with scheduled } \\
\text { mammo appointments } \\
\text { were identified by clinic } \\
\text { records for baseline tel } \\
\text { interview }\end{array}$ & $\begin{array}{l}100 \% \text { female: age 50- } \\
74 \text { yr recruited } \\
\text { through two settings }\end{array}$ & $\begin{array}{l}\text { Four-group } \\
\text { randomized } \\
\text { design }\end{array}$ & 1614: 64\%; NA & $\begin{array}{l}\text { - Obtaining the next } \\
\text { due mammo based } \\
\text { on clinic records }\end{array}$ & $\begin{array}{l}15 \text { mo post- } \\
\text { intervention none }\end{array}$ \\
\hline $\begin{array}{l}\text { Smit West et al. } \\
\text { [52]: USA }\end{array}$ & $\begin{array}{l}\text { (1) Tailored reminder } \\
\text { letter: (2) tailored tel } \\
\text { call to promote mammo } \\
\text { use (at stage } 2 \text { in the } \\
\text { research design) }\end{array}$ & $\begin{array}{l}\text { - Relative risk } \\
\text { - Mammo behavior }\end{array}$ & $\begin{array}{l}\text { Eligible women who } \\
\text { presented the health } \\
\text { clinic in the previous } \\
5 \text { yr, no recent mammo, } \\
\text { randomly selected and } \\
\text { contacted by tel }\end{array}$ & $\begin{array}{l}100 \% \text { female; age } \chi- \\
65 \mathrm{yr} \text { range } 50-80 \mathrm{yr} \text {; } \\
\text { not BC affected; low- } \\
\text { income rural; African } \\
\text { American }\end{array}$ & $\begin{array}{l}\text { Randomized } \\
\text { design }\end{array}$ & $320 ; 67 \% ; 22 \%$ & $\begin{array}{l}\text { - Self-reported } \\
\text { mammo use }\end{array}$ & $\begin{array}{l}6 \text { mo post- } \\
\text { intervention NS }\end{array}$ \\
\hline $\begin{array}{l}\text { Valanis et al. } \\
\text { |31]: USA }\end{array}$ & $\begin{array}{l}\text { (1) In-reach motivational } \\
\text { interview: (2) outreach } \\
\text { tailored letter and } \\
\text { motivational tel counseling: } \\
\text { (3) } 1 \text { and } 2 ; \text { (4) UC }\end{array}$ & $\begin{array}{l}\text { - Barriers to screening } \\
\text {-Age } \\
\text { - Ethnicity: TTM }\end{array}$ & $\begin{array}{l}\text { Female HMO members } \\
\text { aged } 50-69 \text { overdue } \\
\text { for mammogram and } \\
\text { Pap smear }\end{array}$ & $\begin{array}{l}100 \% \text { female; } \mathbb{X}(S D)- \\
59 \text { (5) no bimastectomy }\end{array}$ & RCT & 501: $69 \%$ & $\begin{array}{l}\text { - Mammo and pap-test } \\
\text { screening rates during } \\
\text { the } 14 \text { mo study period } \\
\text { bassed on health plan } \\
\text { electronic records }\end{array}$ & $\begin{array}{l}24 \text { mo screening } \\
\text { rates of group } 2 \\
\text { remained increased } \\
\text { compared to UC } \\
\text { mammo OR }=2.06 \text {. } \\
\text { pap-test OR }=1.97 \\
\text { both OR }=2.53\end{array}$ \\
\hline $\begin{array}{l}\text { Valanis et al. } \\
\text { |32]; USA }\end{array}$ & See Valanis, 2003 & $\begin{array}{l}\text { - Barriers to screening } \\
\text {-Age } \\
\text { - Ethnicity }\end{array}$ & $\begin{array}{l}\text { Female HMO members } \\
\text { aged } 52-69 \text { who had } \\
\text { no mammo in past } \\
2 \text { yr and no pap smear } \\
\text { in the past } 3 \text { yr }\end{array}$ & $\begin{array}{l}100 x \text { female; } x(S D)= \\
59(5)\end{array}$ & RCT & 501: $69 \%$ & $\begin{array}{l}\text { - Mammo and pap-test } \\
\text { screening rates during } \\
\text { the } 14 \text { mo study period } \\
\text { based on health plan } \\
\text { electronic records }\end{array}$ & $\begin{array}{l}14 \text { mo intervention } \\
2 \text { was most effective } \\
\text { with } 39 \% \text { of women } \\
\text { obtaining both } \\
\text { services, } 32 \% \text { of } \\
\text { group } 3 \text { and } 26 \% \\
\text { group } 1 \text { obtained } \\
\text { services compared } \\
\text { to } 19 \% \text { uc }(p<.05)\end{array}$ \\
\hline
\end{tabular}

BC, breast cancer; BSE, breast self-examination; CRC, colorectal cancer; FOBT, fecal occult blood test; HMO, health maintenance organization; Mammo, mammography; mo, month(s); NA, non-applicable; OC, ovarian cancer; PC

BC, breast cancer; BSE, breast self-examination; CRC, colorectal cancer; FOBT, fecal occult blood test; HMO, health maintenance organization; Mammo,
prostate cancer; RCT, randomized controlled trial; UC, usual care; wk, week( $(s)$; yr, years $(s)$; TTM, Trans Theoretical Model; HBM, Health Belief Model.
a If missing this information is not provided in the article.

2 If missing this information is not provided in the article.
$b$ b

ndents divided by the number of (eligible) people invited to participate.

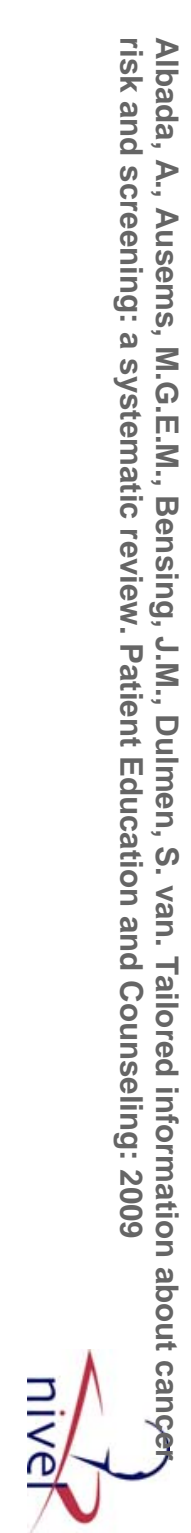


Table 3

Best evidence synthesis for outcome measures of studies on tailored information $(N=28)^{\text {a }}$.

\begin{tabular}{|c|c|c|c|c|c|c|}
\hline Outcome measure & & Type of tailoring variables & Control group & $\begin{array}{l}\text { Number of } \\
\text { studies }\end{array}$ & $\begin{array}{l}\text { Significant positive } \\
\text { effect }(p<.05)\end{array}$ & $\begin{array}{l}\text { Best evidence } \\
\text { synthesis }\end{array}$ \\
\hline \multirow[t]{3}{*}{ Knowledge of } & $\begin{array}{l}\text { Breast cancer and } \\
\text { mammography }\end{array}$ & $\begin{array}{l}\text { Risk factors and } \\
\text { behavioral constructs }\end{array}$ & Standard reminder & $2[29,30]$ & 2 Low quality RCTs & Indicative findings \\
\hline & $\begin{array}{l}\text { Breast cancer and } \\
\text { heredity }\end{array}$ & $\begin{array}{l}\text { Risk factors, behavioral } \\
\text { constructs and information } \\
\text { processing constructs }\end{array}$ & Standard info & 1 [61] & 1 Low quality RCT & Indicative findings \\
\hline & Melanoma & Risk factors & No intervention & $1[28]$ & 1 High quality RCT & Limited evidence \\
\hline \multirow[t]{3}{*}{ Risk perception } & $\begin{array}{l}\text { Accuracy of } \\
\text { perceived cancer risks }\end{array}$ & Risk factors & Standard info & $3[36,42,51]$ & $\begin{array}{l}1 \text { Low [51] and } \\
1 \text { moderate } \\
\text { [36] quality RCT }\end{array}$ & Indicative findings \\
\hline & & & No intervention & $1[28]$ & None & No evidence \\
\hline & & $\begin{array}{l}\text { Risk factors and } \\
\text { behavioral constructs }\end{array}$ & $\begin{array}{l}\text { Standard reminder/ } \\
\text { no intervention }\end{array}$ & $3[19,29,30]$ & $\begin{array}{l}2 \text { Low quality } \\
\text { RCTs }[19,29]\end{array}$ & Indicative findings \\
\hline \multirow{10}{*}{$\begin{array}{l}\text { Screening for } \\
\text { (adherence to } \\
\text { recommended } \\
\text { screening interval) }\end{array}$} & $\begin{array}{l}\text { Breast cancer } \\
\text { (mammography) }\end{array}$ & Risk factors & $\begin{array}{l}\text { Standard or } \\
\text { personalized info }\end{array}$ & $3[35,38,59]$ & $\begin{array}{l}1 \text { Low quality } \\
\text { RCT [59] }\end{array}$ & Insufficient evidence \\
\hline & & $\begin{array}{l}\text { Behavioral constructs } \\
\text { (see Table 4) }\end{array}$ & Standard info & 4 & None & No evidence \\
\hline & & & No intervention & 10 & 6 Low quality RCTs & Indicative findings \\
\hline & & $\begin{array}{l}\text { Risk factors and } \\
\text { behavioral constructs }\end{array}$ & $\begin{array}{l}\text { Standard reminder/ } \\
\text { no intervention }\end{array}$ & $3[20,29,30]$ & None & No evidence \\
\hline & & $\begin{array}{l}\text { Behavioral and } \\
\text { cultural constructs }\end{array}$ & No intervention & $1[40]$ & $\begin{array}{l}1 \text { Moderate } \\
\text { quality RCT }\end{array}$ & Indicative findings \\
\hline & $\begin{array}{l}\text { Cervical cancer } \\
\text { (pap-test) }\end{array}$ & Risk factors & Personalized info & $1[38]$ & None & No evidence \\
\hline & & Behavioral constructs & no intervention & $2[20,48]$ & None & No evidence \\
\hline & $\begin{array}{l}\text { Colorectal cancer } \\
\text { (fecal occult } \\
\text { blood test) }\end{array}$ & Risk factors & Standard info & $1[53]$ & None & No evidence \\
\hline & & $\begin{array}{l}\text { Risk factors and } \\
\text { behavioral constructs }\end{array}$ & Standard info & $1[54]$ & None & No evidence \\
\hline & Skin cancer & Risk factors & No intervention & $1[28]$ & 1 High quality RCT & Limited evidence \\
\hline
\end{tabular}

a Number of studies in the table exceeds 28 because several studies reported more than one outcome measure. 
Table 4

Effects of information tailored on only behavioral constructs on breast cancer screening ${ }^{a}(N=11)$.

\begin{tabular}{|c|c|c|c|c|c|c|}
\hline \multirow[t]{2}{*}{ Study } & \multirow[t]{2}{*}{ Methodological quality } & \multirow[t]{2}{*}{ Population } & \multirow[t]{2}{*}{ Intervention delivery } & \multirow[t]{2}{*}{ Control group } & \multicolumn{2}{|c|}{ Significant effects ${ }^{\mathrm{b}}$} \\
\hline & & & & & Direction & Estimate \\
\hline Champion et al. [27] & Low & HMO members & Printed material & UC (no intervention) & + & $4 \mathrm{mo} \mathrm{OR} 1.07$ \\
\hline Champion et al. [33] & Low & $\begin{array}{l}\text { Visitors of GP, } \\
\text { multi-service centre and } \\
\text { African American convention }\end{array}$ & Computer intervention & Pamphlet only & & None \\
\hline Champion et al. [34] & Low & HMO members & Printed material & UC (no intervention) & + & 2 mo OR 1.72 \\
\hline Clark et al. [18] & Moderate & HMO members & Printed material & $\begin{array}{l}\text { (1) UC (active reminder) } \\
\text { (2) Standard materials }\end{array}$ & + & $\begin{array}{l}\text { ARR } 1.29 \\
\text { None }\end{array}$ \\
\hline Lipkus et al. [41] & Low & HMO members & Printed material & $\begin{array}{l}\text { UC (standard invitation, } \\
2 \text { reminder letters, } \\
\text { physician follow-up) }\end{array}$ & & None \\
\hline McCaul et al. [43] & Low & Medicare participants & Printed letter & $\begin{array}{l}\text { (1) Reminder and } \\
\text { general risk info } \\
\text { (2) reminder }\end{array}$ & & None \\
\hline Prochaska et al. [45] & High & GP patients & Computer intervention & no intervention & & None \\
\hline Rakowski et al. [46] & Moderate & HMO members & Printed materials & $\begin{array}{l}\text { (1) Standard materials } \\
\text { (2) No materials }\end{array}$ & + & $\begin{array}{l}\text { None } \\
19-21 \mathrm{mo} O R=1.43\end{array}$ \\
\hline Rimer et al. [48] & Low & $\begin{array}{l}\text { Community health } \\
\text { centre attendees }\end{array}$ & Printed materials & No information & & None \\
\hline Saywell et al. [49] & Low & GP patients & Printed materials & UC (no intervention) & + & 2 mo OR 1.6 \\
\hline Skinner et al. [26] & Moderate & $\begin{array}{l}\text { HMO members and } \\
\text { clinic patients }\end{array}$ & Printed materials & UC (no intervention) & + & $\begin{array}{l}6 \text { mo booster } \\
\text { vs. none (OR 1.7) }\end{array}$ \\
\hline
\end{tabular}

GP, general practitioner; HMO, health maintenance organization; UC, usual care.

Adherence to recommended screening interval.

For all study participants at $p<.05$ significance level. 


\section{Appendix A. Data extraction form}

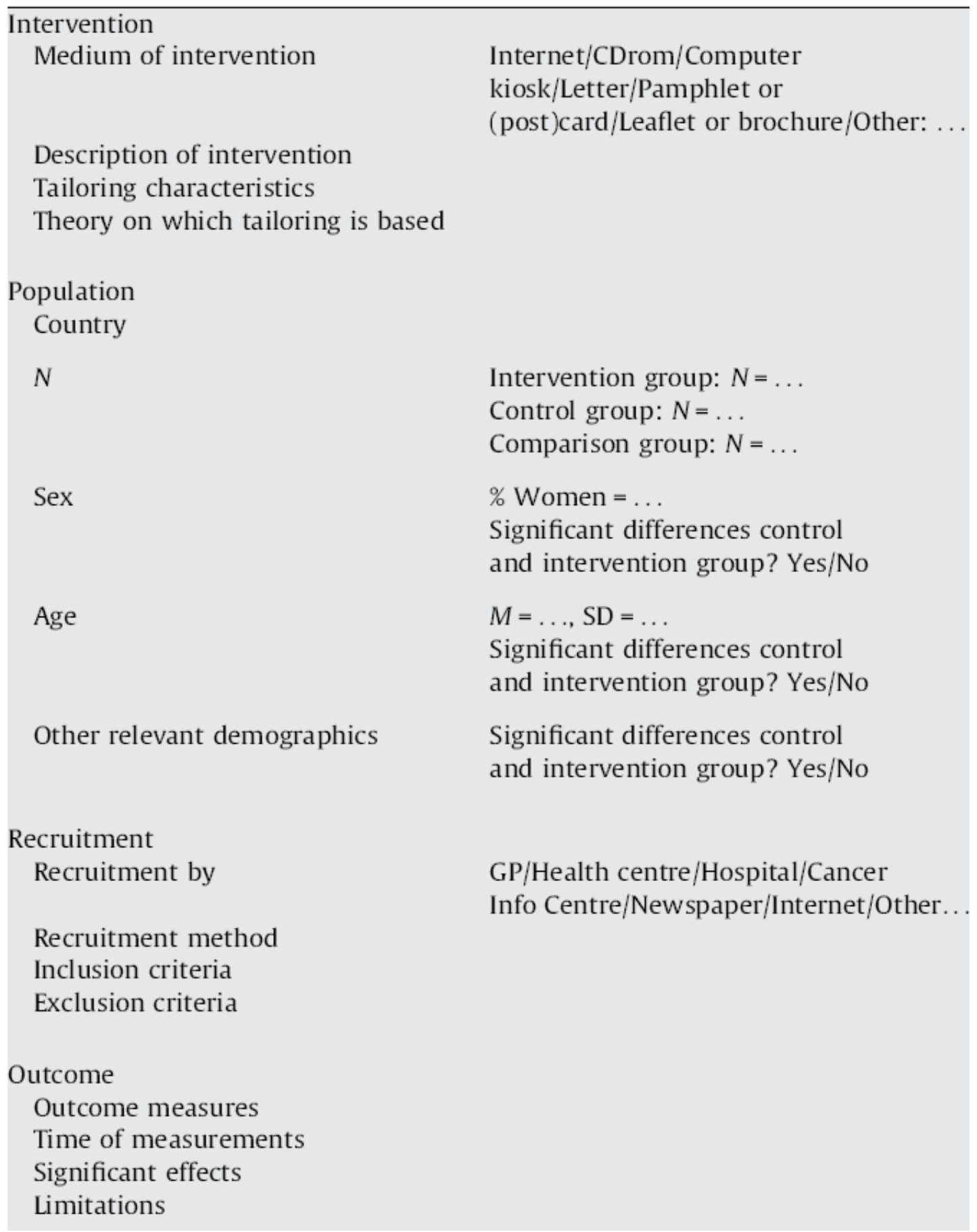




\section{Appendix B. Principles of best evidence synthesis}

\section{Evidence:}

Provided by consistent, statistically significant findings in outcome measures in at least two high quality RCTs.

Moderate evidence:

Provided by consistent, statistically significant findings in outcome measures in at least one high quality RCT and at least one moderate or low quality RCT.

Limited evidence:

Provided by statistically significant findings in outcome measures in at least one high quality RCT.

Indicative findings:

Provided by statistically significant findings in outcome measures in at least one moderate or low quality RCT (in the absence of high quality RCTs)

No/insufficient evidence:

If the number of studies that have significant findings is less than $50 \%$ of the total number of studies found within the same category of methodological quality

Or and study design.

In case the results of eligible studies do not meet the criteria for one of the above stated levels of evidence.

Or

In case of conflicting (statistically significantly positive and statistically significantly negative) results among RCTs.

Or

In case of no eligible studies. 